Published in final edited form as:

J Med Chem. 2015 March 12; 58(5): 2378-2389. doi:10.1021/jm501859j.

\title{
Development of a Novel Class of Tubulin Inhibitor from Desmosdumotin B with a Hydroxylated Bicyclic B-Ring
}

\author{
Kyoko Nakagawa-Goto ${ }^{\star}, \dagger$, , Akifumi Oda ${ }^{\dagger}$, Ernest Hamel $\|$, Emika Ohkoshi ${ }^{\ddagger}$, Kuo-Hsiung \\ Lee $^{\ddagger, \S, \perp}$, and Masuo Goto ${ }^{*}, \ddagger$ \\ †School of Pharmaceutical Sciences, College of Medical, Pharmaceutical and Health Sciences, \\ Kanazawa University, Kanazawa, 920-1192, Japan \\ ¥Natural Product Research Laboratories, Chemical Biology and Medicinal Chemistry, UNC \\ Eshelman School of Pharmacy, University of North Carolina, Chapel Hill, North Carolina \\ 27599-7568, United States \\ §UNC Lineberger Comprehensive Cancer Center, University of North Carolina, Chapel Hill, North \\ Carolina 27599-7295, United States \\ $\|$ Screening Technologies Branch, Developmental Therapeutics Program, Division of Cancer \\ Treatment and Diagnosis, Frederick National Laboratory for Cancer Research, National Cancer \\ Institute, Frederick, Maryland 21702, United States \\ ${ }^{\perp}$ Chinese Medicine Research and Development Center, China Medical University and Hospital, 2 \\ Yuh-Der Road, Taichung, 40447, Taiwan
}

\section{Abstract}
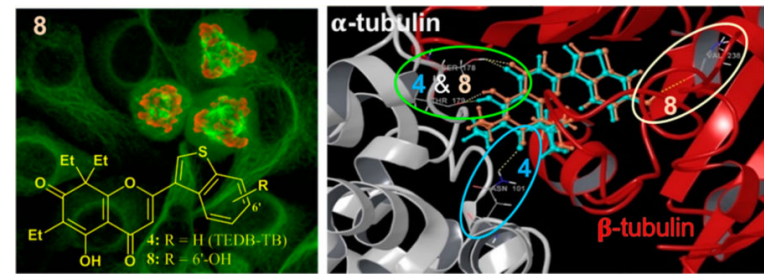

A series of newly synthesized hydroxylated analogues of triethyldesmosdumotin B (TEDB) with a bicyclic B-ring exhibited a significantly different mode of action for affecting microtubule dynamics and spindle formation but had the same antiproliferative activity spectrum, including activity against multidrug-resistant tumors. These analogues efficiently induced cell cycle arrest at prometaphase and caused formation of immature multipolar spindles. 6'-Hydroxyl TEDB-TB (8)

\footnotetext{
(C) 2015 American Chemical Society

*Corresponding Authors: K.N.G.: phone, +81-76-264-6305; kngoto@p.kanazawa-u.ac.jp. *M.G.: phone, +1-919-843-6325; goto@med.unc.edu.

ASSOCIATED CONTENT

Supporting Information

Synthetic procedures of benzo[b]thiophene aldehydes 24-28, standard deviations of cytotoxicity and antitubulin activity, effects of compounds on microtubule dynamics in PC-3 cells, and the docking models of $\mathbf{1 2}$ and DAMA-colchicine. These materials are available free of charge via the Internet at http://pubs.acs.org.

The authors declare no competing financial interest.
} 
disrupted bipolar spindle formation but had a negligible effect on interphase microtubules. On the basis of the predicted binding modes of the new compounds with tubulin dimer, compound 4 forms three hydrogen bonds (H-bonds) only with $a$-tubulin at the colchicine site; in contrast, $\mathbf{8}$ forms $\mathrm{H}$-bonds with both $\alpha$ - and $\beta$-tubulin. We predict that, when a compound/ligand, such as $\mathbf{8}$, forms $\mathrm{H}$-bonds to both $\alpha$ - and $\beta$-tubulins, spindle formation is disrupted more than the dynamics of interphase microtubules. This result may reflect the well-known greater dynamicity of spindle microtubules as compared with interphase microtubules.

\section{INTRODUCTION}

Microtubule-targeting agents are recognized as valuable drugs in the treatment of both solid cancers and hematologic malignancies. ${ }^{1-3}$ Antimicrotubule agents disrupt microtubule dynamics, resulting in disruption of cell cycle progression and, subsequently, induction of cell death. On the basis of the mechanisms of action, antimicrotubule agents are normally categorized into two groups: (i) microtubule disrupters that inhibit the polymerization of tubulin, such as colchicine, vincristine (VIN), podophyllotoxin, and combretastatin A-4 (CA-4), and (ii) microtubule stabilizers that prevent the depolymerization of microtubules, such as paclitaxel (PXL), epothilones, discodermolide, and laulimalide. Depending on their binding domain on tubulin, these antimitotic agents are further classified into (i) colchicine site agents (CSAs), such as colchicine and CA-4; (ii) vinca site agents, such as VIN and vinblastine; (iii) taxane site (on the microtubule interior) agents, such as PXL and epothilones; (iv) laulimalide site (on the microtubule exterior) agents, such as laulimalide and peloruside A; and (v) others. ${ }^{4}$ Importantly, numerous antimicrotubule agents have been identified and developed from natural products. Antimicrotubule agents, especially taxanes and vinca alkaloids, are commonly used in clinical cancer treatment. Furthermore, many microtubule-targeting natural products are currently in clinical trials. However, although antimicrotubule agents are quite useful cancer chemotherapeutics, one major obstacle remains unsolved: innate and acquired drug resistance, notably multidrug resistance (MDR). The best-known gene is MDR-1, encoding P-glycoprotein (P-gp). Overexpression of the $\mathrm{P}$ gp drug transporter leads to poor disease prognosis, ${ }^{5-9}$ and most clinical antimicrotubule drugs are P-gp substrates. [A survey of numerous antimicrotubule agents with a single matched pair of cells, with one of the lines overexpressing P-gp, demonstrated that PXL, docetaxel, ixabepilone, VIN, vinblastine, vinorelbine, and the truncated halichondrin B analogue eribulin were P-gp substrates (Hamel and R. Bai, unpublished data).] A recent study indicated that overexpression of class III $\beta$-tubulin, as well as changes in microtubule regulation, are also associated with MDR to antimicrotubule agents that interact with the taxane or vinca site. ${ }^{10}$ However, interestingly, CSAs were generally active in cells overexpressing class III $\beta$-tubulin. ${ }^{11}$

Although rapidly growing cells, such as tumors, are sensitive to antimicrotubule agents, normal cells are also impacted by disruption of microtubule networks. Because no CSAs are currently used clinically for cancer treatment, the discovery of new antimitotic agents targeting the colchicine site (CS) might be a valuable approach for effective cancer chemotherapy, especially agents that can overcome the MDR phenotype without interfering with interphase microtubule dynamics. 
Desmosdumotin B (DesB, 1), a flavonoid with an unusual nonaromatic trimethylated A-ring (Figure 1), exhibited unique bioactivity against P-gp overexpressing MDR tumor cells. Briefly, 1 displayed selective antiproliferative activity against tumor cell lines overexpressing P-gp, while it was nontoxic against non-MDR tumor cell lines. Its selective index (SI), the $\mathrm{IC}_{50}$ against non-MDR cells divided by the $\mathrm{IC}_{50}$ against MDR cells, was $>20$. This selectivity against MDR lines was greatly enhanced by triethylation of the A-ring, producing $\mathbf{2}$ (TEDB, SI > 220) and $\mathbf{3}(\mathrm{SI}=490) .{ }^{12-14}$ The TEDB analogues with a bicyclic aryl B-ring, such as benzo[b]thiophene 4 (TEDB-TB) and naphthalene 5, displayed a dramatically different bioactivity profile, showing substantial growth inhibition against multiple cancer cell lines. ${ }^{13,15}$ These analogues inhibited tubulin polymerization, in part through the CS. Importantly, none of the analogues were P-gp substrates, and thus, they may be potentially effective against MDR tumors. ${ }^{15}$

Poor water solubility is another major obstacle for the use of antimitotic agents, especially the taxanes. ${ }^{2}$ Generally, the incorporation of a hydroxyl group into a structure can lead to increased polarity as well as polar surface area (PSA), which is connected to oral bioavailability ${ }^{16}$ and correlated with passive intestinal absorption. ${ }^{17,18} \mathrm{cLogP}$ has been used as a parameter of water solubility. In the TEDB-TB series, $\operatorname{cLogP}$ values of the related hydroxyl analogues were reduced by a range of 0.5-0.9 from those of the parent compounds (Supporting Information, Table S1). ${ }^{19}$ In a prior modeling study, the structure of TEDB-TB partially matched with the common pharmacophores conserved in antimicrotubule CSAs. ${ }^{15}$ This same study also suggested that a hydrogen acceptor, such as a hydroxyl group, on the B-ring in TEDB-TB could contribute to an additional common CS-related pharmacophore. Inspired by these analyses, we rationally designed and synthesized various hydroxyl analogues of $\mathbf{4}$ and $\mathbf{5}$ to improve water solubility, as well as to study structure-activity relationships (SARs). A hydroxyl group also allows various functional groups to be introduced into the compound in future modification studies. All synthesized analogues were evaluated for antiproliferative activity against several cancer cell lines, including an MDR tumor cell line. Active analogues were further assessed for potential effects against tubulin assembly in a cell-free system and cell cycle progression in tumor cells. We also performed molecular modeling studies with the analogues bound to tubulin, and these demonstrated a novel mode of H-bond formation in the CS.

In this paper, we describe the syntheses of a series of hydroxyl analogues of $\mathbf{4}$ and $\mathbf{5}$ and the bioactivities of these compounds. We also summarize our molecular modeling results.

\section{RESULTS AND DISCUSSION}

\section{Chemistry}

Hydroxylated analogues 6-20 (Figure 2) were prepared from 2-acetyl-4,4,6-triethyl-3hydroxy-5-methoxycy-clohexa-2,5-dien-1-one (21) using our prior synthetic methodology to produce TEDB (2), ${ }^{12-14}$ as shown in Scheme 1. A Claisen-Schmidt condensation of 21 with various methoxybenzo[b]thiophenecarboxaldehydes 24-28 or commercially available methoxynaphthaldehydes 29-31 provided the related chalcones $\mathbf{2 2}$ in good yield. The resulting chalcones were cyclized in the presence of catalytic iodine and concd $\mathrm{H}_{2} \mathrm{SO}_{4}$. 
Demethylation of 23 with $\mathrm{BBr}_{3}$ produced the desired hydroxyl analogues $\mathbf{6 - 9 ,} \mathbf{1 4 - 1 6}$, and 19. Methoxy analogues 10-12 were obtained as minor products during the demethylation step. Depending on the reaction conditions, the methoxy group on the A-ring was removed faster than that on the B-ring. Compounds 13, 17, 18, and 20 were previously synthesized. ${ }^{15}$ The required benzo[b]thiophene aldehydes 24-27 were constructed as shown in Scheme 2. The condensation of $p$-, $m$-, and $o$-methoxybenzenethiols (32-34) with $a$-chloro ketone, followed by cyclization with polyphosphoric acid at $100{ }^{\circ} \mathrm{C}$, afforded 5-methoxy-3methylbenzo[b]thiophenes (35) from 32, 4- and 6-methoxy derivatives (36 and 37) from 33, and the 7-methoxy derivative (38) from $\mathbf{3 4} .^{20}$ The C-3 methyl group of 35-38 was converted by radical bromination to a bromomethyl group, which was then formylated by using a Sommelet reaction to obtain the desired 3-carboxaldehydes 24-27. ${ }^{21}$ On the other hand, 3bromobenzo[b]thiophene (43) was converted to 3-methoxybenzo[b]thiophene (44), ${ }^{22}$ which was formylated with DMF through 2-lithiation to obtain 2-carbaldehyde $\mathbf{2 8}$.

\section{Antiproliferative Effects and SAR Analysis}

All new analogues were evaluated for antiproliferative activity against 10 human tumor cell lines: KB (originally isolated from epidermoid carcinoma of the nasopharynx), KB-subline KB-VIN showing MDR phenotype with overexpression of P-gp, PC-3 (prostate cancer), A549 (lung carcinoma), HepG2 (hepatocellular carcinoma), HCT-8 (colon adenocarcinoma), and four breast cancer cell lines (MDA-MD-231, SK-BR-3, MCF-7, and ZR-75-1) (Table 1). The antiproliferative effects of the compounds were assessed by the sulforhodamine $\mathrm{B}(\mathrm{SRB})$ assay, and $\mathrm{IC}_{50}$ values were calculated from at least three independent experiments, each performed in duplicate.

Among the benzo $[b]$ thiophen-3'-yl analogues, all four hydroxyl derivatives 6-9 showed potent antiproliferative effects against the tested tumor cell lines, including the P-gpoverexpressing MDR tumor cell line. In contrast, the corresponding methoxy derivatives 10-12 were less active. The position of the hydroxyl group on the B-ring had a strong influence on activity against HCT-8 tumor cells. Compared with $\mathbf{6}$ and $\mathbf{8}$, hydroxyl analogues $\mathbf{7}$ and $\mathbf{9}$, which have a hydroxy group at the para- or ortho-position, respectively, relative to the sulfur atom, exhibited more than 5-fold reduced inhibitory effect against HCT-8, while the activity against the other tumor cell lines was not noticeably affected. The $3^{\prime}$-hydroxybenzo- $[b]$ thiophen-2'-yl analogue $\mathbf{1 4}$ showed similar cytotoxicity to the nonhydroxylated parent compound $\mathbf{1 3}$ against all tested tumor cell lines except PC-3, against which 14 displayed 4-fold reduced activity.

In the case of the 1'-naphthyl derivatives, the insertion of a hydroxyl group on $\mathbf{1 5}$ and $\mathbf{1 6}$ generally resulted in slightly better antiproliferative activity as compared with parent compound 5. This trend was not seen in the benzo[b]-thiophene analogues. In particular, the antiproliferative effects of $\mathbf{1 6}$ against $\mathrm{HepG}$, KB, and KB-VIN were 2-6 times greater than that of the parent compound $\mathbf{5}$. In addition, unlike the benzo[b]thiophene analogues, methoxynaphthalene derivative $\mathbf{1 7}$ also inhibited tumor cell growth with $\mathrm{IC}_{50}$ values of 1.5$3.6 \mu \mathrm{M}$. These values differed little from those obtained with the related hydroxyl derivative 16. The hydroxynaphthalen-2'-yl derivative 19 was generally 10 -fold less active than the hydroxynaphthalen-1'-yl derivatives $\mathbf{1 5}$ and $\mathbf{1 6}$, while no differences were found between 
the activities of $\mathbf{5}$ (naphthalen-1'-yl) and $\mathbf{1 8}$ (naphthalen-2'-yl). Overall, in this flavonoid series, the results indicated that the addition of a hydroxyl functionality to a bicyclic B-ring system on the first ring directly connected to the chromene skeleton caused slightly enhanced activity, although addition of a hydroxyl group on the second ring not directly connected to the chromene skeleton generally reduced activity. This SAR study is summarized in Figure 3.

Importantly, all analogues displayed potent antiproliferative effects against KB-VIN, a MDR KB subline overexpressing Pgp. The antiproliferative activities of 7-10, 12-14, 16, and 19 against KB-VIN were even greater than those against the parent KB non-MDR tumor cell line. This fact indicates that these analogues are not P-gp substrates and could be effective against tumors expressing the MDR phenotype.

\section{Inhibition of Tubulin Polymerization and Colchicine Binding to Tubulin}

Cytotoxic analogues 4-9 and 15-18 were tested for inhibitory effects on tubulin assembly as well as inhibition of $\left[{ }^{3} \mathrm{H}\right]$ colchicine binding to tubulin, using highly purified bovine brain tubulin. Table 1 lists the 50\% effective concentration for inhibiting tubulin assembly $\left(\mathrm{EC}_{50^{-}}\right.$ ITA) and the percent inhibition of colchicine binding to tubulin (ICB) in the presence of compounds 4-9 and 15-18, as well as results obtained with the CS antimicrotubule agent CA-4 as a positive control. Standard deviations can be found in the Supporting Information. Analogue 6 with a 4'-hydroxyl strongly inhibited tubulin assembly with an $\mathrm{EC}_{50}$-ITA value of $2.8 \mu \mathrm{M}$ and inhibited colchicine binding by $70 \%$. The data for $\mathbf{4}$ and $\mathbf{6}$ were very similar, despite the more than 10-fold difference in their antiproliferative effects against tumor cells. These results suggest that both compounds bind to tubulin and inhibit its polymerization, while 6 may be detoxified in the tumor cells more rapidly than 4 . The disparate results between antiproliferative and tubulin inhibitory effects were also observed for other analogues. 4'-Hydroxyl analogue $\mathbf{6}$ and 6'-hydroxyl analogue 8 comparably inhibited tumor cell growth, but the inhibitory effects on tubulin assembly and colchicine binding of $\mathbf{6}$ were 2 -fold greater than those of $\mathbf{8}$. These results prompted us to perform additional investigations on hydroxyl analogs $\mathbf{6}$ and $\mathbf{8}$, as well as $\mathbf{4}$, using human tumor cell lines. It should be noted that original natural product 1 showed no effects on tubulin assembly in a cell-free system (Table 1) or in KB-VIN cells (data not shown).

\section{Induction of Cell Cycle Arrest at the G2/M Phase in MDR Tumor Cells}

Small molecules showing antimicrotubule activity, such as colchicine, VIN, and PXL, inhibit cell cycle progression at the G2/M phase in chemosensitive tumors. However, these compounds are ineffective against MDR tumors, because overexpressed ABC transporter(s) efficiently efflux these compounds. ${ }^{5}$ To see if the newly synthesized compounds affected the cell cycle in MDR tumor cells, the cell cycle progression of treated KB-VIN and parental KB cells was analyzed by flow cytometry (Figure 4). PXL at $0.02 \mu \mathrm{M}$ significantly impacted the cell cycle in KB cells, while PXL at $3 \mu \mathrm{M}$ did not show any effect in the KB-VIN cells, demonstrating that PXL is efficiently effluxed from the MDR tumor cell by overexpressed P-gp. In contrast, accumulation of cells in the G2/M phase, as well as the S-phase, was observed in both chemosensitive (KB) and MDR cells (KB-VIN) treated with $\mathbf{4}$ and its analogues at identical concentrations. Cell cycle progression was also disrupted by 
compounds in a time-dependent manner. These results support the data found in the antiproliferative assays (Table 1) and indicate that MDR cells do not efflux $\mathbf{4}$ and its analogues.

\section{Morphological Variations of Microtubule Dynamics by Antimicrotubule Agents in Tumor Cells}

In the current study, immunofluorescence visualization of tubulin in PC-3 cells was used to clearly show distinguishable disruptions of microtubule dynamics upon treatment with different anti-microtubule agents binding to diverse sites, such as CA-4 binding to the CS, VIN binding to the vinca site, and PXL binding to the taxane site (Figure 5). In particular, microtubule morphology in mitotic PC-3 cells treated with $\mathbf{4}$ was not identical to those in mitotic cells treated with other tested antimicrotubule agents, while it was similar to that in interphase cells treated with CA-4 (Supporting Information, Figure S1). These results suggest that the mode of action of $\mathbf{4}$ is to inhibit tubulin polymerization in the interphase by a mechanism similar to that of CA-4, but different from CA-4 at the time of mitotic spindle formation.

\section{Modification Sites in TEDB Skeleton Have Differing Effects on Microtubule Polymerization}

To further understand the effects of the new hydroxyl-modified $\mathbf{4}$ analogues on microtubule dynamics and on the cell cycle, dose-dependent morphological microtubule defects were analyzed in PC-3 cells (Figure 6; Supporting Information, Figure S2). Flow cytometric analysis clearly demonstrated that all hydroxylated 4 analogues induced significant cell cycle accumulation in the G2/M phase (Figure 6A). To determine whether the cell cycle arrest was due to an antimicrotubule effect, cells treated with compound were analyzed by triple staining with antibodies to $a$-tubulin and the mitotic marker Ser10-phosphorylated histone H3 (p-H3) and with 4',6-diamidino-2-phenylindole (DAPI) for DNA. In cells treated with compounds, multiple spindles were seen in the p-H3 positive cells (Figure 6B,C). The results demonstrated that the new compounds inhibited normal bipolar spindle formation and induced cell cycle arrest at the G2/M phase, probably at prometaphase. However, the impact of $\mathbf{4}$ analogues on spindle formation was different from that of other antimicrotubule agents. While multipolar spindles formed partially in cells treated with test compounds, no spindles were detected after treatment with CA-4 or PXL (Figure 6B,C and Supporting Information, Figure S2). While inhibition of spindle formation corresponded directly to depolymerization of interphase microtubules in cells treated with CA-4 or with $\mathbf{4 , 6}$, or $\mathbf{9}$, disrupted spindle formation was observed in conjunction with normally polymerized interphase microtubules in cells treated with $\mathbf{7}$ or $\mathbf{8}$. Compound $\mathbf{7}$ was less active than $\mathbf{8}$. Furthermore, analysis of microtubule morphology in the presence of different doses of $\mathbf{8}$ demonstrated that the normal morphology of interphase microtubules in the presence of $\mathbf{8}$ did not result from partial inhibition of tubulin polymerization. Interestingly, stabilized interphase microtubules were observed in cells treated with a high concentration $(20 \mu \mathrm{M})$ of $\mathbf{7}$ or $\mathbf{8}$. Thus, compounds $\mathbf{7}$ and $\mathbf{8}$ selectively disrupted spindle formation without depolymerizing interphase microtubules (Figure 6B,C and Supporting Information, Figure S2). In contrast, using CA-4, it was not possible to determine a concentration that was less effective against interphase microtubule polymerization than spindle formation. At the concentration of CA-4 that inhibited interphase microtubule polymerization, accumulated p- 
H3 (Ser10)-positive cells showed no spindle formation. These cell-based observations suggested that compounds $\mathbf{7}$ and $\mathbf{8}$, especially $\mathbf{8}$, are more effective against the more dynamic spindles than the less dynamic interphase microtubules and, thus, interact with tubulin in a manner distinct from that of CA-4 and of $\mathbf{4 , 6}$, and $\mathbf{9}$.

We next used molecular docking studies to investigate the binding of $\mathbf{8}$ to the tubulin dimer. Our goal was to determine whether the compound(s) might have distinct binding properties that could explain the different antimicrotubule effects of compounds $\mathbf{4}$ and $\mathbf{8}$, as well as colchicine, on tumor cells.

\section{Computer Modeling}

The theoretical binding mode of TEDB-TBs at the CS in the tubulin dimer was investigated by using entry $1 \mathrm{SA} 0$ in the Protein Data Bank as a structure of the $\alpha \beta$-tubulin dimer. In this crystal structure, $N$-deacetyl- $N$-(2-mercaptoacetyl)colchicine (DAMA-colchicine), a close analogue of colchicine, was used to illustrate its binding to the CS. ${ }^{23}$ Colchicine is known to bind at the interface between the $\alpha$ - and $\beta$-subunits, extending toward the $\beta$-subunit (Supporting Information, Figure S3A). ${ }^{24}$ Loop 7 (T7), strands 8 and 9, as well as helixes 7 and 8 (H7 and $\mathrm{H} 8$ ), where the $\beta$-subunit connects to loop 5 (T5) of the $\alpha$-subunit, are critical for interactions of ligand and protein in the CS. We previously reported ${ }^{15}$ that the benzo[b]thiophenyl B-ring of $\mathbf{4}$ and the colchicine A-ring showed common pharmacophores acting as hydrophobic centers. The overlapped 3D model of $\mathbf{4}$ and colchicine (Figure 7A) also supported this prior finding, showing that both rings were oriented in the same direction. This partial similarity in the 3D model complemented the similar effects on inhibition of microtubule polymerization in a cell-free system (Table 1), as well as in cultured cells (Figure 5).

In the tubulin binding assay described above (Table 1), CA-4 inhibited $99 \%$ of colchicine binding to tubulin, while $\mathbf{4}$ or $\mathbf{8}$ inhibited $78 \%$ or $39 \%$, respectively. Thus, we expected that 4 and its hydroxyl analogues, especially 8 , would show a different mode of binding to the CS. An overview of the binding modes of $\mathbf{4}$ and $\mathbf{8}$ in the crystal structure of the $\alpha \beta$-tubulin dimer did show overlap with DAMA-colchicine (Figure 7B). However, as expected, a detailed docking model of 4 (Figure 8A) revealed a considerable difference from that of DAMA-colchicine (Supporting Information, Figure S3A), and 8 also showed a distinct binding mode (Figure 8B-D and Supporting Information, Figure S3B). The benzo[b]thiophenyl B-ring of $\mathbf{4}$ was located in the pocket on $\beta$-tubulin. Accordingly, any substituents on this ring might directly affect the binding affinity with amino acid(s) on $\beta$ tubulin and the shape of the binding pocket. The unsaturated A-ring of $\mathbf{4}$ was positioned toward $\alpha$-tubulin, with the $\mathrm{C}-6$ ethyl group forced into the open space between $\alpha$ - and $\beta$ tubulin, while the $\mathrm{C}-8$ geminal ethyl groups were held entirely in $\beta$-tubulin. While the 3 methoxy group on colchicine's A-ring generates an important interaction with the side chain of Cys241 in $\beta$-tubulin ( $\beta$ Cys 241 ) (note that numbering of $\beta$-tubulin residues follows the modeling convention used in ref 23 rather than the actual sequence numbers) (Supporting Information, Figure S3A), ${ }^{23}$ neither of the TEDB-TB analogues interacted with $\beta$ Cys 241 . Instead, the docked model of analogue 4 showed H-bonds with the side chains of $a$ Asn101, $a$ Ser178, and $a$ Thr179 (Figure 8A). With analogue 8, the side chain of $\beta V$ al238 formed an 
H-bond with the C-6' hydroxyl group; however, the H-bond found between the C-7 oxygen of 4 and $\alpha$ Asn101 was not present (Figure 8B-D and Supporting Information, Figure S3B). We made the following conclusions based on the docking models of 4 and 8: (1) Bioactive TEDB-TBs 4 and 8 have two oxygen atoms on C-4 and C-5 in the chromone skeleton, and the C-4 and C-5 oxygen atoms form H-bonds with $\alpha$ Ser178 and $\alpha$ Thr179, respectively. (2) The H-bond between $a$ Asn 101 and the C-7 oxygen atom of $\mathbf{4}$ could be a critical factor for inhibition of tubulin polymerization. (3) The force of the H-bond between $\beta \mathrm{Val} 238$ and the C-6' hydroxyl group of $\mathbf{8}$ could prevent formation of the H-bond with $a$ Asn101 observed in 4.

The models for the binding of TEDB-TBs to tubulin show great dependence on amino acid residues of the $\alpha$-tubulin, rather than the $\beta$-tubulin, subunit, which differs from other CS agents and, thus, could explain some of the properties of the TEDB-TBs. All four hydroxyl benzo[b]thiophen-3-yl analogues 6-9 and lead compound $\mathbf{4}$ bound in the same place on tubulin with similar docking structures, although the $7^{\prime}-\mathrm{OH}$ analogue 9 was slightly shifted from the docking pattern of the other compounds (Figure 9A,B). This difference indicated that the binding pocket around the $7^{\prime}$-position either did not have enough space to accommodate a hydroxyl group or generated an electronic disruption.

Unexpectedly, the distance between the A-ring carbonyl oxygen on $\mathbf{9}$ and the nitrogen on $a$ Asn101 (N-O distance) was not large (3.076 $)$ ), despite the slight shift in the docking mode of 9 as described above. Furthermore, analogue $\mathbf{6}$ displayed the smallest N-O distance $(2.563 \AA)$, although an unsuitable $\mathrm{N}-\mathrm{H} \cdots \mathrm{O}$ angle $\left(111.6^{\circ}\right)$ appeared to prevent $\mathrm{H}$-bond formation. For 4, the N-O distance was $3.091 \AA$, which is more than $0.8 \AA$ shorter than that of 8 (Figure 9D). Accordingly, analogues 4 and $\mathbf{6}$ were located closer to $a$ Asn101 than analogues $\mathbf{7}$ and 8 (Figure 9C). This result might explain why analogues 4 and $\mathbf{6}$ exhibited greater tubulin depolymerization activity than analogues $\mathbf{7}$ and $\mathbf{8}$. The distinction between the H-bonding modes of $\mathbf{4}$ and $\mathbf{8}$ might be relevant to their distinct antimicrotubule activities in cultured cells. Accordingly, like CA-4, compounds $\mathbf{4}$ and $\mathbf{6}$ disrupted interphase microtubule dynamics as well as spindle formation, while interphase microtubules were intact in cells treated with $\mathbf{7}$ and $\mathbf{8}$ at the effective dose that induced cell cycle arrest by inhibiting spindle formation (Figure 6).

Finally, it should be noted that the C-7' methoxy group in analogue $\mathbf{1 2}$ appeared to be located similarly to, but about $2 \AA$ inside, an A-ring methoxy group on colchicine. Thus, the $7^{\prime}$-OMe group might be too close to the $\beta \mathrm{Val} 238$ and $\beta \mathrm{Thr} 239$ positions and could disturb the binding affinity (Supporting Information, Figure S4).

In summary, hydroxyl- or methoxy-substituted TEDB-TB analogues 6-20 were synthesized and evaluated for in vitro antiproliferative activity, for effects on cell cycle progression, and for interactions with purified tubulin. Hydroxyl naphthalene derivatives 15 and $\mathbf{1 6}$ inhibited growth of multiple tumor cell lines more strongly than their parent compound $\mathbf{5}$. All hydroxyl analogues showed potent antiproliferative activity, while methoxy analogues were less active. Active analogues induced cell cycle arrest at the G2/M phase, especially at the prometaphase by disrupting spindle formation. All cytotoxic hydroxyl analogues targeted tubulin. Molecular modeling indicated that the hydroxyl benzo[b]thiophene analogues 
interacted with the CS in distinct binding modes. Disruption of interphase microtubules by the benzo[b]thiophene analogues was altered by modification of the parent compound with hydroxyl groups in a site-dependent manner.

Computational docking models suggested that all TEDB-TB analogues bound to the tubulin heterodimer at the CS, but considerable differences were observed in H-bond formations with CS amino acids. This binding mode diversity could be attributable to the modification of the benzo[ $b]$ thiophene moiety with hydroxyl groups. In particular, $a$ Asn101, $a$ Ser178, and $\alpha \mathrm{Thr} 179$ and $\beta$ Val238 contributed to stable H-bonds with TEDB-TB analogues. Compound 4, which disrupted both interphase microtubules and mitotic spindle formation, and compound $\mathbf{8}$, which disrupted only spindle formation, formed H-bonds with only $a$ tubulin or with both $\alpha$ - and $\beta$-tubulin, respectively. Thus, we speculate that interphase microtubule dynamics are less affected or even not disrupted at all when a TEDB-TB analogue/ligand, such $\mathbf{8}$, formed several H-bonds with both $\alpha$ - and $\beta$-tubulin.

While clinically successful tubulin inhibitors target both the mitotic spindle and interphase microtubules in chemosensitive cancer cells, some of our new analogues effectively inhibited bipolar spindle formation without interfering with interphase microtubule dynamics in both chemosensitive and MDR cancer cells. Therefore, these TEDB analogues might be promising candidates leading to a new chemotherapeutic drug targeted at tubulin and also could possibly overcome MDR obstacles, as well as reducing undesirable effects in slowly growing normal cells.

\section{EXPERIMENTAL SECTION}

All chemicals and solvents were used as purchased. All melting points were measured on a Fisher-Johns melting point apparatus and are reported without correction. ${ }^{1} \mathrm{H}$ and ${ }^{13} \mathrm{C}$ NMR spectra were recorded on a Varian Gemini 2000 (300 MHz) or Varian Inova (400 MHz) NMR spectrometer with TMS as the internal standard. All chemical shifts are reported in ppm. NMR spectra are referenced to the residual solvent peak, chemical shifts $\delta$ are in ppm, and apparent scalar coupling constants $J$ are in hertz. Mass spectroscopic data were obtained on a Shimadzu LCMS-IT-TOF instrument. Analytical thin-layer chromatography (TLC) was carried out on Merck precoated aluminum silica gel sheets (Kieselgel 60 F-254). Biotage Flash or Isco Companion systems were used for flash chromatography. All target compounds were characterized and determined to be at least $>95 \%$ pure by ${ }^{1} \mathrm{H}$ NMR and analytical HPLC.

\section{General Synthetic Procedures for 22}

A solution of 21 in EtOH-50\% aq KOH (1:1, v/v) and an appropriate aromatic aldehyde (excess) was stirred at room temperature. After the reaction was complete, as judged by TLC analysis, the mixture was poured into ice-cold $1 \mathrm{~N} \mathrm{HCl}$ and then extracted with $\mathrm{CH}_{2} \mathrm{Cl}_{2}$. The extract was washed with brine, dried over $\mathrm{Na}_{2} \mathrm{SO}_{4}$, and concentrated in vacuo. The residue was chromatographed on silica gel with $\mathrm{CH}_{2} \mathrm{Cl}_{2}$-hexane as eluent to afford the target compound $\mathbf{2 2}$ in 78\%-95\% yield (based on recovery of starting material). 


\section{General Synthetic Procedures for 4-20}

Compound 22 was dissolved in DMSO containing $1 \% \mathrm{H}_{2} \mathrm{SO}_{4}$, then $\mathrm{I}_{2}(0.1$ mol equiv) was added. The mixture was heated at $90{ }^{\circ} \mathrm{C}$ for $1 \mathrm{~h}$. The reaction mixture was quenched with ice-cold aqueous $10 \% \mathrm{Na}_{2} \mathrm{~S}_{2} \mathrm{O}_{3}$ and extracted three times with EtOAc. The combined organic layers were washed with brine, dried over $\mathrm{Na}_{2} \mathrm{SO}_{4}$, and concentrated in vacuo. The residue was purified by silica gel chromatography with EtOAc-hexane as eluent to afford crude compound 23 , which was dissolved in anhydrous $\mathrm{CH}_{2} \mathrm{Cl}_{2}$. $\mathrm{BBr}_{3}(3 \mathrm{~mol}$ equiv, $1.0 \mathrm{M}$ solution in $\mathrm{CH}_{2} \mathrm{Cl}_{2}$ ) was added to the solution at $0{ }^{\circ} \mathrm{C}$, which was allowed to warm to $\mathrm{rt}$ and stirred overnight. After addition of water, the reaction mixture was extracted three times with $\mathrm{CH}_{2} \mathrm{Cl}_{2}$. The combined organic layers were washed with brine, dried over $\mathrm{Na}_{2} \mathrm{SO}_{4}$, and concentrated in vacuo. The residues were chromatographed on silica gel, eluting with EtOAc-hexane (1:4) to obtain analogues 6-9, 14-16, and 19, as well as 10-12, 17, and 20 as minor products.

\section{2-(4' -Hydroxybenzo[b]thiophen-3'-yl)-6,8,8-triethyldesmos-dumotin B (6)}

${ }^{1} \mathrm{H}$ NMR $\left(300 \mathrm{MHz}, \mathrm{CDCl}_{3}, \delta\right): 13.12\left(\mathrm{~s}, 1 \mathrm{H}\right.$, chelated-OH), $7.75\left(\mathrm{~s}, 1 \mathrm{H}, 2^{\prime}-H\right), 7.61(\mathrm{~d}, 1 \mathrm{H}$, $J=8.0 \mathrm{~Hz}, 5^{\prime}$ or $\left.7^{\prime}-H\right), 7.31\left(\mathrm{dd}, 1 \mathrm{H}, J=7.8\right.$ and $\left.8.0 \mathrm{~Hz}, 6^{\prime}-H\right), 6.99$ (s, $\left.1 \mathrm{H}, 3-H\right), 6.90(\mathrm{~d}$, $1 \mathrm{H}, J=7.8 \mathrm{~Hz}, 5^{\prime}$ or $\left.7^{\prime}-H\right), 2.47\left(\mathrm{q}, 2 \mathrm{H}, J=7.3 \mathrm{~Hz}, 6-\mathrm{CH}_{2} \mathrm{CH}_{3}\right), 2.21-2.10(\mathrm{~m}, 2 \mathrm{H}, 8-$ $\mathrm{CH}_{2} \mathrm{CH}_{3}$ ), 2.03-1.91 (m, 2H, 8- $\left.\mathrm{CH}_{2} \mathrm{CH}_{3}\right), 1.06\left(\mathrm{t}, 3 \mathrm{H}, J=7.3 \mathrm{~Hz}, 6-\mathrm{CH}_{2} \mathrm{CH}_{3}\right), 0.68$ (t, 6H, $J$ $\left.=7.3 \mathrm{~Hz}, 8-\mathrm{CH}_{2} \mathrm{CH}_{3} \times 2\right)$. HRMS $(\mathrm{m} / \mathrm{z}):[\mathrm{M}+\mathrm{H}]^{+}$calcd for $\mathrm{C}_{23} \mathrm{H}_{23} \mathrm{O}_{5} \mathrm{~S}, 411.1261$; found, 411.1249 .

\section{2-(5'-Hydroxybenzo[b]thiophen-3' -yl)-6,8,8-triethyldesmos-dumotin B (7)}

${ }^{1} \mathrm{H}$ NMR $\left(300 \mathrm{MHz}, \mathrm{CDCl}_{3}, \delta\right): 13.10\left(\mathrm{~s}, 1 \mathrm{H}\right.$, chelated-OH), $8.08\left(\mathrm{~s}, 1 \mathrm{H}, 2^{\prime}-H\right), 7.80(\mathrm{~d}, 1 \mathrm{H}$, $\left.J=8.7 \mathrm{~Hz}, 7^{\prime}-H\right), 7.57\left(\mathrm{~d}, 1 \mathrm{H}, J=2.3 \mathrm{~Hz}, 4^{\prime}-H\right), 7.10\left(\mathrm{dd}, 1 \mathrm{H}, J=8.7\right.$ and $\left.2.3 \mathrm{~Hz}, 6^{\prime}-H\right)$, 6.95 (s, $1 \mathrm{H}, 2-H), 5.55$ (s, $\left.1 \mathrm{H}, 5^{\prime}-\mathrm{OH}\right), 2.47$ (q, $\left.2 \mathrm{H}, J=7.3 \mathrm{~Hz}, 6-\mathrm{CH}_{2} \mathrm{CH}_{3}\right), 2.34-2.23$ (m, $\left.2 \mathrm{H}, 8-\mathrm{CH}_{2} \mathrm{CH}_{3}\right), 2.06-1.96\left(\mathrm{~m}, 2 \mathrm{H}, 8-\mathrm{CH}_{2} \mathrm{CH}_{3}\right), 1.06\left(\mathrm{t}, 3 \mathrm{H}, J=7.3 \mathrm{~Hz}, 6-\mathrm{CH}_{2} \mathrm{CH}_{3}\right), 0.71$ $\left(\mathrm{t}, 6 \mathrm{H}, J=7.3 \mathrm{~Hz}, 8-\mathrm{CH}_{2} \mathrm{CH}_{3} \times 2\right)$. HRMS $(\mathrm{m} / \mathrm{z})$ : $[\mathrm{M}+\mathrm{H}]^{+}$calcd for $\mathrm{C}_{23} \mathrm{H}_{23} \mathrm{O}_{5} \mathrm{~S}, 411.1261$; found, 411.1258 .

\section{2-(6'-Hydroxybenzo[b]thiophen-3' -yl)-6,8,8-triethyldesmos-dumotin B (8)}

${ }^{1} \mathrm{H}$ NMR (300 MHz, $\left.\mathrm{CDCl}_{3}, \delta\right): 13.11$ (s, $1 \mathrm{H}$, chelated-OH), 7.94 (d, $1 \mathrm{H}, J=8.8 \mathrm{~Hz}, 4^{\prime}-H$ ), $7.88\left(\mathrm{~s}, 1 \mathrm{H}, 2^{\prime}-H\right), 7.41\left(\mathrm{~d}, 1 \mathrm{H}, J=2.3 \mathrm{~Hz}, 7^{\prime}-H\right), 7.12\left(\mathrm{dd}, 1 \mathrm{H}, J=8.8\right.$ and $\left.2.3 \mathrm{~Hz}, 5^{\prime}-H\right)$, $6.90(\mathrm{~s}, 1 \mathrm{H}, 3-\mathrm{H}), 5.62\left(\mathrm{~s}, 1 \mathrm{H}, 6^{\prime}-\mathrm{OH}\right), 2.48\left(\mathrm{q}, 2 \mathrm{H}, \mathrm{J}=7.4 \mathrm{~Hz}, 6-\mathrm{CH}_{2} \mathrm{CH}_{3}\right), 2.34-2.21(\mathrm{~m}$, $\left.2 \mathrm{H}, 8-\mathrm{CH}_{2} \mathrm{CH}_{3}\right), 2.05-1.94\left(\mathrm{~m}, 2 \mathrm{H}, 8-\mathrm{CH}_{2} \mathrm{CH}_{3}\right), 1.06\left(\mathrm{t}, 3 \mathrm{H}, J=7.4 \mathrm{~Hz}, 6-\mathrm{CH}_{2} \mathrm{CH}_{3}\right), 0.71$ $\left(\mathrm{t}, 6 \mathrm{H}, J=7.4 \mathrm{~Hz}, 8-\mathrm{CH}_{2} \mathrm{CH}_{3} \times 2\right)$. HRMS $(\mathrm{m} / z)$ : $[\mathrm{M}+\mathrm{H}]^{+}$calcd for $\mathrm{C}_{23} \mathrm{H}_{23} \mathrm{O}_{5} \mathrm{~S}, 411.1261$; found, 411.1258 .

\section{2-(7'-Hydroxybenzo[b]thiophen-3'-yl)-6,8,8-triethyldesmos-dumotin B (9)}

${ }^{1} \mathrm{H}$ NMR $\left(300 \mathrm{MHz}, \mathrm{CDCl}_{3}, \delta\right): 13.12(\mathrm{~s}, 1 \mathrm{H}$, chelated-OH), 8.07 (s, $1 \mathrm{H}, 2-H), 7.68(\mathrm{~d}, 1 \mathrm{H}$, $\left.J=8.1 \mathrm{~Hz}, 4^{\prime}-H\right), 7.43\left(\mathrm{dd}, 1 \mathrm{H}, J=7.8\right.$ and $\left.8.1 \mathrm{~Hz}, 5^{\prime}-H\right), 6.94(\mathrm{~s}, 1 \mathrm{H}, 3-H), 6.92(\mathrm{~d}, 1 \mathrm{H}, J=$ $7.8 \mathrm{~Hz}, 6-\mathrm{H}), 6.10\left(\mathrm{~s}, 1 \mathrm{H}, 7^{\prime}-\mathrm{OH}\right), 2.48\left(\mathrm{q}, 2 \mathrm{H}, J=7.4 \mathrm{~Hz}, 6-\mathrm{CH}_{2} \mathrm{CH}_{3}\right), 2.34-2.12(\mathrm{~m}, 2 \mathrm{H}, 8-$ $\left.\mathrm{CH}_{2} \mathrm{CH}_{3}\right), 2.08-1.96\left(\mathrm{~m}, 2 \mathrm{H}, 8-\mathrm{CH}_{2} \mathrm{CH}_{3}\right), 1.06\left(\mathrm{t}, 3 \mathrm{H}, J=7.4 \mathrm{~Hz}, 6-\mathrm{CH}_{2} \mathrm{CH}_{3}\right), 0.72(\mathrm{t}, 6 \mathrm{H}, J$ 
$\left.=7.4 \mathrm{~Hz}, 8-\mathrm{CH}_{2} \mathrm{CH}_{3} \times 2\right)$. HRMS $(\mathrm{m} / \mathrm{z}):[\mathrm{M}+\mathrm{H}]^{+}$calcd for $\mathrm{C}_{23} \mathrm{H}_{23} \mathrm{O}_{5} \mathrm{~S}, 411.1261$; found, 411.1250 .

2-(4'-Methoxybenzo[b]thiophen-3' -yl)-6,8,8-triethyldes-mosdumotin B (10)

${ }^{1} \mathrm{H}$ NMR $\left(300 \mathrm{MHz}, \mathrm{CDCl}_{3}, \delta\right): 13.21\left(\mathrm{~s}, 1 \mathrm{H}\right.$, chelated-OH), $7.66\left(\mathrm{~s}, 1 \mathrm{H}, 2^{\prime}-H\right), 7.53(\mathrm{~d}, 1 \mathrm{H}$, $\left.J=8.0 \mathrm{~Hz}, 7^{\prime}-H\right), 7.42\left(\mathrm{t}, 1 \mathrm{H}, J=8.0 \mathrm{~Hz}, 6^{\prime}-H\right), 6.88\left(\mathrm{~d}, 1 \mathrm{H}, J=8.0 \mathrm{~Hz}, 5^{\prime}-H\right), 6.71(\mathrm{~s}, 1 \mathrm{H}$, 3- $H$ ), 3.85 (s, 3H, 4'-OCH ${ }_{3}$ ), 2.47 (q, $2 \mathrm{H}, J=7.4 \mathrm{~Hz}, 6-\mathrm{CH}_{2} \mathrm{CH}_{3}$ ), 2.19-2.09 (m, 2H, 8$\left.\mathrm{CH}_{2} \mathrm{CH}_{3}\right), 1.94-1.83\left(\mathrm{~m}, 2 \mathrm{H}, 8-\mathrm{CH}_{2} \mathrm{CH}_{3}\right), 1.06\left(\mathrm{t}, 3 \mathrm{H}, J=7.4 \mathrm{~Hz}, 6-\mathrm{CH}_{2} \mathrm{CH}_{3}\right), 0.68$ (t, 6H, $J$ $\left.=7.4 \mathrm{~Hz}, 8-\mathrm{CH}_{2} \mathrm{CH}_{3} \times 2\right)$. HRMS $(\mathrm{m} / \mathrm{z}):[\mathrm{M}+\mathrm{H}]^{+}$calcd for $\mathrm{C}_{24} \mathrm{H}_{25} \mathrm{O}_{5} \mathrm{~S}, 425.1417$; found, 425.1415 .

\section{2-(5'-Methoxybenzo[b]thiophen-3'-yl)-6,8,8-triethyldes-mosdumotin B (11)}

${ }^{1} \mathrm{H}$ NMR $\left(300 \mathrm{MHz}, \mathrm{CDCl}_{3}, \delta\right): 13.10\left(\mathrm{~s}, 1 \mathrm{H}\right.$, chelated-OH), $8.05\left(\mathrm{~s}, 1 \mathrm{H}, 2^{\prime}-H\right), 7.82(\mathrm{~d}, 1 \mathrm{H}$, $\left.J=8.9 \mathrm{~Hz}, 7^{\prime}-H\right), 7.49(\mathrm{t}, 1 \mathrm{H}, J=2.3 \mathrm{~Hz}, 4-H), 7.15\left(\mathrm{dd}, 1 \mathrm{H}, J=8.9\right.$ and $\left.2.3 \mathrm{~Hz}, 6^{\prime}-H\right), 6.89$ (s, $1 \mathrm{H}, 3-H), 3.91$ (s, 3H, 5'-OCH $\left.{ }_{3}\right), 2.47$ (q, $\left.2 \mathrm{H}, J=7.5 \mathrm{~Hz}, 6-\mathrm{CH}_{2} \mathrm{CH}_{3}\right), 2.34-2.22(\mathrm{~m}, 2 \mathrm{H}$, 8- $\left.\mathrm{CH}_{2} \mathrm{CH}_{3}\right), 2.07-1.96\left(\mathrm{~m}, 2 \mathrm{H}, 8-\mathrm{CH}_{2} \mathrm{CH}_{3}\right), 1.06\left(\mathrm{t}, 3 \mathrm{H}, \mathrm{J}=7.5 \mathrm{~Hz}, 6-\mathrm{CH}_{2} \mathrm{CH}_{3}\right), 0.71(\mathrm{t}$, $\left.6 \mathrm{H}, J=7.5 \mathrm{~Hz}, 8-\mathrm{CH}_{2} \mathrm{CH}_{3} \times 2\right)$. HRMS $(\mathrm{m} / \mathrm{z}):[\mathrm{M}+\mathrm{H}]^{+}$calcd for $\mathrm{C}_{24} \mathrm{H}_{25} \mathrm{O}_{5} \mathrm{~S}, 425.1417$; found, 425.1402 .

\section{2-(7'-Methoxybenzo[b]thiophen-3'-yl)-6,8,8-triethyldes-mosdumotin B (12)}

${ }^{1} \mathrm{H}$ NMR $\left(300 \mathrm{MHz}, \mathrm{CDCl}_{3}, \delta\right): 13.10\left(\mathrm{~s}, 1 \mathrm{H}\right.$, chelated-OH), $8.05\left(\mathrm{~s}, 1 \mathrm{H}, 2^{\prime}-H\right), 7.68(\mathrm{~d}, 1 \mathrm{H}$, $\left.J=8.2 \mathrm{~Hz}, 7^{\prime}-H\right), 7.51\left(\mathrm{dd}, 1 \mathrm{H}, J=7.8\right.$ and $\left.8.2 \mathrm{~Hz}, 6^{\prime}-H\right), 6.93(\mathrm{~s}, 1 \mathrm{H}, 3-H), 6.93(\mathrm{~d}, 1 \mathrm{H}, J=$ $\left.7.8 \mathrm{~Hz}, 5^{\prime}-\mathrm{H}\right), 4.06$ (s, 3H, 7'-OCH$\left.{ }_{3}\right), 2.47$ (q, $\left.2 \mathrm{H}, J=7.3 \mathrm{~Hz}, 6-\mathrm{CH}_{2} \mathrm{CH}_{3}\right), 2.32-2.21(\mathrm{~m}$, $\left.2 \mathrm{H}, 8-\mathrm{CH}_{2} \mathrm{CH}_{3}\right), 2.06-1.94\left(\mathrm{~m}, 2 \mathrm{H}, 8-\mathrm{CH}_{2} \mathrm{CH}_{3}\right), 1.06$ (t, $\left.3 \mathrm{H}, J=7.3 \mathrm{~Hz}, 6-\mathrm{CH}_{2} \mathrm{CH}_{3}\right), 0.71$ $\left(\mathrm{t}, 6 \mathrm{H}, J=7.3 \mathrm{~Hz}, 8-\mathrm{CH}_{2} \mathrm{CH}_{3} \times 2\right)$. HRMS $(\mathrm{m} / \mathrm{z})$ : $[\mathrm{M}+\mathrm{H}]^{+}$calcd for $\mathrm{C}_{24} \mathrm{H}_{25} \mathrm{O}_{5} \mathrm{~S}, 425.1417$; found, 425.1420 .

\section{2-(3'-Hydroxybenzo[b]thiophen-2' -yl)-6,8,8-triethyldesmos-dumotin B (14)}

${ }^{1} \mathrm{H}$ NMR (300 MHz, $\mathrm{CDCl}_{3}, \delta$ ): 12.81 (s, $1 \mathrm{H}$, chelated-OH), 11.65 (br s, $1 \mathrm{H}, 3^{\prime}-\mathrm{OH}$ ), 8.23-8.17 (m, 1H), $8.04(\mathrm{~s}, 1 \mathrm{H}, 3-H), 7.84-7.79(\mathrm{~m}, 1 \mathrm{H}), 7.59-7.53(\mathrm{~m}, 2 \mathrm{H}), 2.51(\mathrm{q}, 2 \mathrm{H}, J=$ $\left.7.5 \mathrm{~Hz}, 6-\mathrm{CH}_{2} \mathrm{CH}_{3}\right), 2.35-2.23\left(\mathrm{~m}, 2 \mathrm{H}, 8-\mathrm{CH}_{2} \mathrm{CH}_{3}\right), 2.12-2.00\left(\mathrm{~m}, 2 \mathrm{H}, 8-\mathrm{CH}_{2} \mathrm{CH}_{3}\right), 1.09$ (t, $\left.3 \mathrm{H}, J=7.5 \mathrm{~Hz}, 6-\mathrm{CH}_{2} \mathrm{CH}_{3}\right), 0.71\left(\mathrm{t}, 6 \mathrm{H}, J=7.5 \mathrm{~Hz}, 8-\mathrm{CH}_{2} \mathrm{CH}_{3} \times 2\right)$. HRMS $(\mathrm{m} / z):[\mathrm{M}+$ $\mathrm{H}]^{+}$calcd for $\mathrm{C}_{23} \mathrm{H}_{23} \mathrm{O}_{5} \mathrm{~S}, 411.1261$; found, 411.1251 .

\section{2-(4' -Hydroxynaphthalen-1' -yl)-6,8,8-triethyldesmosdumo-tin B (16)}

${ }^{1} \mathrm{H}$ NMR (300 MHz, $\left.\mathrm{CDCl}_{3}, \delta\right): 13.25(\mathrm{~s}, 1 \mathrm{H}$, chelated-OH), 8.41-8.36 (m, $1 \mathrm{H}$, naphthalenyl- $H$ ), 7.98-7.92 (m, $1 \mathrm{H}$, naphthalenyl- $H), 7.65-7.58(\mathrm{~m}, 2 \mathrm{H}$, naphthalenyl- $H$ ), $7.56(\mathrm{~d}, 1 \mathrm{H}, J=8.0 \mathrm{~Hz}$, naphthalenyl- $H$ ), $6.97(\mathrm{~d}, 1 \mathrm{H}, J=8.0 \mathrm{~Hz}$, naphthalenyl- $H$ ), 6.79 (s, $1 \mathrm{H}, 3-\mathrm{H}$ ), 6.70 (br s, $1 \mathrm{H}, 4^{\prime}-\mathrm{OH}$ ), 2.50 (q, $2 \mathrm{H}, J=7.4 \mathrm{~Hz}, 6-\mathrm{CH}_{2} \mathrm{CH}_{3}$ ), 2.26-2.16 (m, 2H, 8$\mathrm{CH}_{2} \mathrm{CH}_{3}$ ), 1.99-1.88 (m, 2H, 8- $\left.\mathrm{CH}_{2} \mathrm{CH}_{3}\right), 1.07$ (t, $\left.3 \mathrm{H}, J=7.4 \mathrm{~Hz}, 6-\mathrm{CH}_{2} \mathrm{CH}_{3}\right), 0.73$ (t, 6H, $J$ $\left.=7.4 \mathrm{~Hz}, 8-\mathrm{CH}_{2} \mathrm{CH}_{3} \times 2\right)$. HRMS $(\mathrm{m} / z)$ : $[\mathrm{M}+\mathrm{H}]^{+}$calcd for $\mathrm{C}_{25} \mathrm{H}_{25} \mathrm{O}_{5}, 405.1696$; found, 405.1680 . 


\section{2-(6'-Hydroxynaphthalen-2' -yl)-6,8,8-triethyldesmosdumo-tin B (19)}

${ }^{1} \mathrm{H} \mathrm{NMR}\left(300 \mathrm{MHz}, 3 \% \mathrm{CD}_{3} \mathrm{OD} / \mathrm{CDCl}_{3}, \delta\right): 13.21$ (s, $1 \mathrm{H}$, chelated-OH), 8.23 (br s, $1 \mathrm{H}$, naphthalenyl- $H$ ), $7.87(\mathrm{~d}, 1 \mathrm{H}, J=8.8 \mathrm{~Hz}$, naphthalenyl- $H), 7.80(\mathrm{~d}, 1 \mathrm{H}, J=8.8 \mathrm{~Hz}$, naphthalenyl- $H$ ), $7.72(\mathrm{dd}, 1 \mathrm{H}, J=8.8$ and $1.9 \mathrm{~Hz}$, naphthalenyl- $H), 7.26-7.19(\mathrm{~m}, 2 \mathrm{H}$, naphthalenyl- $H$ ), 6.98 (s, $1 \mathrm{H}, 3-H), 2.48$ (q, $\left.2 \mathrm{H}, J=7.4 \mathrm{~Hz}, 6-\mathrm{CH}_{2} \mathrm{CH}_{3}\right), 2.35-2.24(\mathrm{~m}, 2 \mathrm{H}$, 8- $\mathrm{CH}_{2} \mathrm{CH}_{3}$ ), 2.13-2.01 (m, 2H, 8- $\left.\mathrm{CH}_{2} \mathrm{CH}_{3}\right), 1.06\left(\mathrm{t}, 3 \mathrm{H}, J=7.4 \mathrm{~Hz}, 6-\mathrm{CH}_{2} \mathrm{CH}_{3}\right), 0.70$ (t, $\left.6 \mathrm{H}, J=7.4 \mathrm{~Hz}, 8-\mathrm{CH}_{2} \mathrm{CH}_{3} \times 2\right)$. HRMS $(\mathrm{m} / \mathrm{z})$ : $[\mathrm{M}+\mathrm{H}]^{+}$calcd for $\mathrm{C}_{25} \mathrm{H}_{25} \mathrm{O}_{5}, 405.1696$; found, 405.1679 .

\section{Antiproliferative Activity Assay}

All stock cell lines were grown in T-75 flasks at $37{ }^{\circ} \mathrm{C}$ with $5 \% \mathrm{CO}_{2}$ in air. Freshly trypsinized cell suspensions were seeded in 96-well microtiter plates at densities of 4000-12 000 cells per well (based on the doubling time of the cell line) with compounds. The highest concentration of DMSO in the cultures $(0.1 \% \mathrm{v} / \mathrm{v})$ was without effect on cell growth under the culture conditions used. After $72 \mathrm{~h}$ in culture with test compounds, attached cells were fixed with $50 \%$ trichloroacetic acid and then stained with $0.04 \%$ sulforhodamine B. After solubilizing the protein-bound dye with $10 \mathrm{mM}$ Tris base, absorbance at $515 \mathrm{~nm}$ was measured using a microplate reader (ELx800, BioTek) with Gen5 software (BioTek). The mean $\mathrm{IC}_{50}$ is the concentration of agent that reduced cell growth by $50 \%$ compared with vehicle (DMSO) control under the experimental conditions used and is the average from at least three independent experiments with duplicate samples. All values presented in Table 1 are statistically significant. The following human tumor cell lines were used in the assay: A549 (lung carcinoma), HepG2 (hepatocellular carcinoma), HCT-8 (colon adenocarcinoma), KB (originally isolated from epidermoid carcinoma of the nasopharynx), KB-VIN (VIN-resistant KB subline showing MDR phenotype by overexpressing P-gp), MCF-7 (estrogen-receptor-positive, HER2-negative breast cancer), PC-3 (androgeninsensitive prostate cancer), SK-BR-3 (estrogen-receptor-negative, progesterone-receptornegative, HER2-overexpressing breast cancer), ZR-75-1 (estrogen-receptor-positive, HER2overexpressing breast cancer). All cell lines were obtained from the Lineberger Comprehensive Cancer Center (UNC-CH) or from ATCC (Manassas, VA), except KB-VIN, which was a generous gift of Prof. Y.-C. Cheng (Yale University). Cells were cultured in RPMI-1640 medium supplemented with $2 \mathrm{mM}_{\mathrm{L}}$-glutamine and $25 \mathrm{mM}$ HEPES (HyClone), supplemented with $10 \%$ heat-inactivated fetal bovine serum (HyClone), $100 \mu \mathrm{g} / \mathrm{mL}$ streptomycin, $100 \mathrm{IU} / \mathrm{mL}$ penicillin, and $0.25 \mu \mathrm{g} / \mathrm{mL}$ amphotericin B (Cellgro). MDR stock cells (KB-VIN) were maintained in the presence of $100 \mathrm{nM}$ VIN.

\section{Tubulin Assays}

Inhibitory effects of compounds against electro-phoretically homogeneous bovine brain tubulin were as described previously. ${ }^{25,26}$ Tubulin assembly assay mixtures contained 1.0 $\mathrm{mg} / \mathrm{mL}(10 \mu \mathrm{M})$ tubulin and varying compound concentrations and were preincubated for 15 min at $30{ }^{\circ} \mathrm{C}$ without guanosine $5^{\prime}$-triphosphate (GTP). The samples were placed on ice, and $0.4 \mathrm{mM}$ GTP was added. Reaction mixtures were transferred to $0{ }^{\circ} \mathrm{C}$ cuvettes, and turbidity development was followed for $20 \mathrm{~min}$ at $30^{\circ} \mathrm{C}$ following a rapid temperature jump. Compound concentrations as $\mathrm{EC}_{50}$ values that inhibited the increase in turbidity by $50 \%$ 
relative to a control sample were determined. In colchicine inhibition assays, tubulin (1.0 $\mu \mathrm{M})$ was incubated with $5.0 \mu \mathrm{M}\left[{ }^{3} \mathrm{H}\right]$ colchicine and $5.0 \mu \mathrm{M}$ test compound at $37{ }^{\circ} \mathrm{C}$ for 10 min, when about $40-60 \%$ of maximum colchicine binding occurs in control samples.

\section{Cell Cycle Analysis}

Distribution of cells in the cell cycle was evaluated by measurement of the cellular DNA content by propidium iodide (PI) (BD Biosciences) staining. Briefly, cells were seeded in 12-well culture plates $\mathbf{2 4} \mathrm{h}$ prior to treatment with compounds. PXL was used at 0.02 or 3 $\mu \mathrm{M}$ for chemosensitive (KB) or MDR (KB-VIN) cells, respectively. Both KB and KB-VIN cells were treated with $0.5 \mu \mathrm{M} 4$ or $2 \mu \mathrm{M} \mathrm{8}$, and vehicle (DMSO) was used as a control. For PC-3 cells, compounds 4 or 6-9 were used at $2 \mu \mathrm{M}$. After a $24 \mathrm{~h}$ treatment, supernatants and trypsinized cells were collected together, followed by centrifugation for $5 \mathrm{~min}$ at $1000 \mathrm{rpm}$. The pellet was resuspended with PBS and fixed in $70 \% \mathrm{EtOH}$ overnight at $-20^{\circ} \mathrm{C}$, followed by staining with PI overnight at $4{ }^{\circ} \mathrm{C}$. Stained cells were analyzed by flow cytometry (FACS LSRII, BD Biosciences). Experiments were repeated a minimum of three times.

\section{Immunofluorescence Staining}

PC-3 cells were grown on an 8-well chamber slide (Lab-Tech) for $24 \mathrm{~h}$ prior to treatment with compound at equicytotoxic compound concentrations. The equi-cytotoxic compound concentrations were determined on the basis of their $\mathrm{IC}_{50}$ and/or the effective concentration used for cell cycle analysis as follows: $0.2 \mu \mathrm{M} \mathrm{4,} 0.2 \mu \mathrm{M}$ CA-4, $5 \mu \mathrm{M}$ VIN, $0.2 \mu \mathrm{M}$ PXL, and $1 \mu \mathrm{M}$ colchicine (Figure 5 and Supporting Information, Figure S1). PC-3 cells were also treated with different doses of compounds 4 or 6-9 at 0.2 , 2, and $20 \mu \mathrm{M}$. CA-4 was used at $0.002,0.02$, and $20 \mu \mathrm{M}$ (Figure 6 and Supporting Information, Figure S2). After treatment of cells with agent for $24 \mathrm{~h}$, cells were fixed with $4 \%$ paraformaldehyde in PBS and permeabilized with $0.5 \%$ Triton X-100 in PBS. Fixed cells were labeled with mouse monoclonal antibody to $\alpha$-tubulin (B5-1-2, Sigma) and rabbit IgG to Ser10-phosphorylated histone H3 (p-H3) (\#06570, EMD Millipore), followed by FITC-conjugated antibody to mouse IgG (Sigma) and Alexa Fluor 549-conjugated antibody to rabbit IgG (Life Technologies). Nuclei were labeled with DAPI (Sigma). Fluorescently labeled cells were observed using an Olympus BX61 fluorescence microscope (Olympus), and images were captured by an ORCA-R ${ }^{2}$ digital camera (Hamamatsu Photonics) with Volocity 5.5.2 software (PerkinElmer Inc.). Microtubules, p-H3, and DNA were also detected using a confocal microscope (Zeiss, LSM700) with ZEN (black edition) software (Zeiss). Confocal images were stacked and merged using ZEN (black edition) software. Experiments were repeated at least twice for each compound at each concentration. Final images were prepared using Adobe Photoshop CS3.

\section{Computer Modeling}

Three-dimensional (3D) structures of tubulin-ligand complexes were predicted by GOLD 5.1 software with default settings. The 3D structure of human tubulin (TUBA1A and TUBB2B) used in this study was constructed from a Protein Data Bank entry (PDB ID: 1SA0). ${ }^{23}$ Missing hydrogen atoms in the crystal structure were computationally added by Hermes. ${ }^{28}$ The center of the active site was defined as the center of the ligand in 1SA0, and 
the active site radius was set to 10.0 A. For the docking calculations, the quantum chemically optimized structures of ligands were used as initial structures. The structural optimizations of ligands were carried out by B3LYP/6-311+G(df,p) using Gaussian 09, Revision B. $01 .^{29}$

\section{Supplementary Material}

Refer to Web version on PubMed Central for supplementary material.

\section{ACKNOWLEDGMENTS}

We wish to thank the Microscopy Service Laboratory (UNC-CH) for their expertise in fluorescence microscopy and confocal microscopy as well as Dr. Leaf Huang (UNC-CH) for use of his flow cytometer. In addition, we appreciate critical comments, suggestions, and editing of the manuscript by Dr. Susan L. Morris-Natschke (UNC$\mathrm{CH})$. This study was supported by a Grant-in-Aid from the Ministry of Education, Culture, Sports, Science and Technology (MEXT KAKENHI, Japan) awarded to K.N.G. (Grant Number 25293024 \& 25670054) and A.O. (Grant Number 23790137), by a grant from Terumo Life Science Foundation awarded to K.N.G., by NIH grant CA177584 from the National Cancer Institute awarded to K.H.L., and by a grant from the Junior Faculty Development Awards (UNC) as well as the University Research Council (UNC) awarded to M.G.

\section{ABBREVIATIONS USED}

$\begin{array}{ll}\text { CA-4 } & \text { combretastatin A-4 } \\ \text { CSA } & \text { colchicine site agent } \\ \text { CS } & \text { colchicine site } \\ \text { DAMA-colchicine } & N \text {-deacetyl- } N \text {-(2-mercaptoacetyl)colchicine } \\ \text { DAPI } & 4^{\prime}, 6 \text {-diamidino-2-phenylindole } \\ \text { DesB } & \text { desmosdumotin B } \\ \text { DMF } & N, N \text {-dimethylformamide } \\ \text { H-bond } & \text { hydrogen bond } \\ \text { IC50 } & \text { concentration that inhibits 50\% human tumor cell growth } \\ \text { ICB } & \text { inhibition of colchicine binding } \\ \text { ITA } & \text { inhibition of tubulin assembly } \\ \text { MDR } & \text { multidrug resistance } \\ \text { PBS } & \text { phosphate-buffered saline } \\ \text { P-gp } & \text { P-glycoprotein } \\ \text { PXL } & \text { paclitaxel } \\ \text { SAR } & \text { structure-activity relationship } \\ \text { TEDB } & 6,8,8 \text {-triethyldesmosdumotin B } \\ \text { TEDB-TB } & 2 \text {-(benzo[b]thiophene-3'-yl)-6,8,8-triethyldesmosdumotin B } \\ \text { VIN } & \text { vincristine }\end{array}$




\section{REFERENCES}

1. Dumontet C, Jordan MA. Microtubule-binding agents: A dynamic field of cancer therapeutics. Nat. Rev. Drug Discovery. 2010; 9:790-803.

2. Risinger AL, Giles FJ, Mooberry SL. Microtubule dynamics as a target in oncology. Cancer Treat. Rev. 2009; 35:255-261. [PubMed: 19117686]

3. Jordan MA, Wilson L. Microtubules as a target for anticancer drugs. Nat. Rev. Cancer. 2004; 4:253-265. [PubMed: 15057285]

4. Lu Y, Chen J, Xiao M, Li W, Miller DD. An overview of tubulin inhibitors that interact with the colchicine binding site. Pharm. Res. 2012; 29:2943-2971. [PubMed: 22814904]

5. Eckford PD, Sharom FJ. ABC efflux pump-based resistance to chemotherapy drugs. Chem. Rev. 2009; 109:2989-3011. [PubMed: 19583429]

6. Fojo T, Menefee M. Mechanisms of multidrug resistance: The potential role of microtubulestabilizing agents. Ann. Oncol. 2007; 18:3-8.

7. Yeh JJ, Hsu WH, Wang JJ, Ho ST, Kao A. Predicting chemotherapy response to paclitaxel-based therapy in advanced nonsmall-cell lung cancer with P-glycoprotein expression. Respiration. 2003; 70:32-35. [PubMed: 12584388]

8. Leonard GD, Fojo T, Bates SE. The role of ABC transporters in clinical practice. Oncologist. 2003; 8:411-424. [PubMed: 14530494]

9. Ling V. Multidrug resistance: Molecular mechanisms and clinical relevance. Cancer Chemother. Pharmacol. 1997; 40:S3-S8. [PubMed: 9272126]

10. Kavellaris M. Microtubules and resistance to tubulin-binding agents. Nat. Rev. Cancer. 2010; 10:194-204. [PubMed: 20147901]

11. Stengel C, Newman SP, Leese MP, Potter BV, Reed MJ, Purohit A. Class III beta-tubulin expression and in vitro resistance to microtubule targeting agents. Br. J. Cancer. 2010; 102:316324. [PubMed: 20029418]

12. Nakagawa-Goto K, Bastow KF, Wu JH, Tokuda H, Lee KH. Total synthesis and bioactivity of unique flavone desmosdumotin B and its analogs. Bioorg. Med. Chem. Lett. 2005; 15:3016-3019. [PubMed: 15913998]

13. Nakagawa-Goto K, Bastow KF, Chen TH, Morris-Natschke SL, Lee KH. Antitumor agents. 260. New desmosdumotin B analogues with improved in vitro anticancer activity. J. Med. Chem. 2008; 51:3297-3303. [PubMed: 18473435]

14. Nakagawa-Goto K, Chang PC, Lai CY, Hung HY, Chen TH, Wu PC, Zhu H, Sedykh A, Bastow KF, Lee KH. Antitumor agents. 280. Multidrug resistance-selective desmosdumotin B analogues. J. Med. Chem. 2010; 53:6699-6705. [PubMed: 20735140]

15. Nakagawa-Goto K, Wu PC, Lai CY, Hamel E, Zhu H, Zhang L, Kozaka T, Ohkoshi E, Goto M, Bastow KF, Lee KH. Antitumor agents. 284. New desmosdumotin B analogues with bicyclic Bring as cytotoxic and antitubulin agents. J. Med. Chem. 2011; 54:1244-1255. [PubMed: 21284385]

16. Kelder J, Grootenhuis PD, Bayada DM, Delbressine LP, Ploemen JP. Polar molecular surface as a dominating determinant for oral absorption and brain penetration of drugs. Pharm. Res. 1999; 16:1514-1519. [PubMed: 10554091]

17. Egan WJ, Merz KM Jr, Baldwin JJ. Prediction of drug absorption using multivariate statistics. J. Med. Chem. 2000; 43:3867-3877. [PubMed: 11052792]

18. Clark DE. Rapid calculation of polar molecular surface area and its application to the prediction of transport phenomena. 1. Prediction of intestinal absorption. J. Pharm. Sci. 1999; 8:807-814. [PubMed: 10430547]

19. cLogP and PSA were calculated by using ChemBioDraw 13 software, as described in the Supporting Information

20. Matsunaga N, Kaku T, Itoh F, Tanaka T, Hara T, Miki H, Iwasaki M, Aono T, Yamaoka M, Kusaka M, Tasaka A. C17,20-Lyase inhibitors. I Structure-based de novo design and SAR study of C17,20-lyase inhibitors. Bioorg. Med. Chem. 2004; 12:2251-2273. [PubMed: 15080924] 
21. Campaigne E, Bosin T, Neiss ES. The sulfur analog of serotonin. J. Med. Chem. 1967; 10:270271. [PubMed: 6034077]

22. Fournier J, Chabert D, Joucla L, David E, Lemaire M. An efficient phosphine-free palladium coupling for the synthesis of new 2-arylbenzo [b] thiophenes. Tetrahedron. 2004; 60:3221-3230.

23. Ravelli RB, Gigant B, Curmi PA, Jourdain I, Lachkar S, Sobel A, Knossow M. Insight into tubulin regulation from a complex with colchicine and a stathmin-like domain. Nature. 2004; 428:198202. see also the Supporting Information. [PubMed: 15014504]

24. Dorleans A, Gigant B, Ravelli RB, Mailliet P, Mikol V, Knossow M. Variations in the colchicinebinding domain provide insight into the structural switch of tubulin. Proc. Natl. Acad. Sci. U. S. A. 2009; 106:13775-13779. [PubMed: 19666559]

25. Hamel E. Evaluation of antimitotic agents by quantitative comparisons of their effects on the polymerization of purified tubulin. Cell Biochem. Biophys. 2003; 38:1-22. [PubMed: 12663938]

26. Verdier-Pinard P, Lai JY, Yoo HD, Yu J, Marquez B, Nagle DG, Nambu M, White JD, Falck JR, Gerwick WH, Day BW, Hamel E. Structure-activity analysis of the interaction of curacin A, the potent colchicine site antimitotic agent, with tubulin and effects of analogs on the growth of MCF-7 breast cancer cells. Mol. Pharmacol. 1998; 53:62-76. [PubMed: 9443933]

27. Jones G, Willett P, Glen RC. Molecular recognition of receptor sites using a genetic algorithm with a description of desolvation. J. Mol. Biol. 1995; 245:43-53. [PubMed: 7823319]

28. Hermes 5.1. Cambridge, UK: CCDC Software Ltd; 2012.

29. Frisch, MJ.; Trucks, GW.; Schlegel, HB.; Scuseria, GE.; Robb, MA.; Cheeseman, JR.; Scalmani, G.; Barone, V.; Mennucci, B.; Petersson, GA.; Nakatsuji, H.; Caricato, M.; Li, X.; Hratchian, HP.; Izmaylov, AF.; Bloino, J.; Zheng, G.; Sonnenberg, JL.; Hada, M.; Ehara, M.; Toyota, K.; Fukuda, R.; Hasegawa, J.; Ishida, M.; Nakajima, T.; Honda, Y.; Kitao, O.; Nakai, H.; Vreven, T.; Montgomery, JA.; Peralta, JE., Jr; Ogliaro, F.; Bearpark, M.; Heyd, JJ.; Brothers, E.; Kudin, KN.; Staroverov, VN.; Keith, T.; Kobayashi, R.; Normand, J.; Raghavachari, K.; Rendell, A.; Burant, JC.; Iyengar, SS.; Tomasi, J.; Cossi, M.; Rega, N.; Millam, JM.; Klene, M.; Knox, JE.; Cross, JB.; Bakken, V.; Adamo, C.; Jaramillo, J.; Gomperts, R.; Stratmann, RE.; Yazyev, O.; Austin, AJ.; Cammi, R.; Pomelli, C.; Ochterski, JW.; Martin, RL.; Morokuma, K.; Zakrzewski, VG.; Voth, GA.; Salvador, P.; Dannenberg, JJ.; Dapprich, S.; Daniels, AD.; Farkas, O.; Foresman, JB.; Ortiz, JV.; Cioslowski, J.; Fox, DJ. Gaussian 09 (Revision B.01). Wallingford, CT: Gaussian, Inc; 2010. 


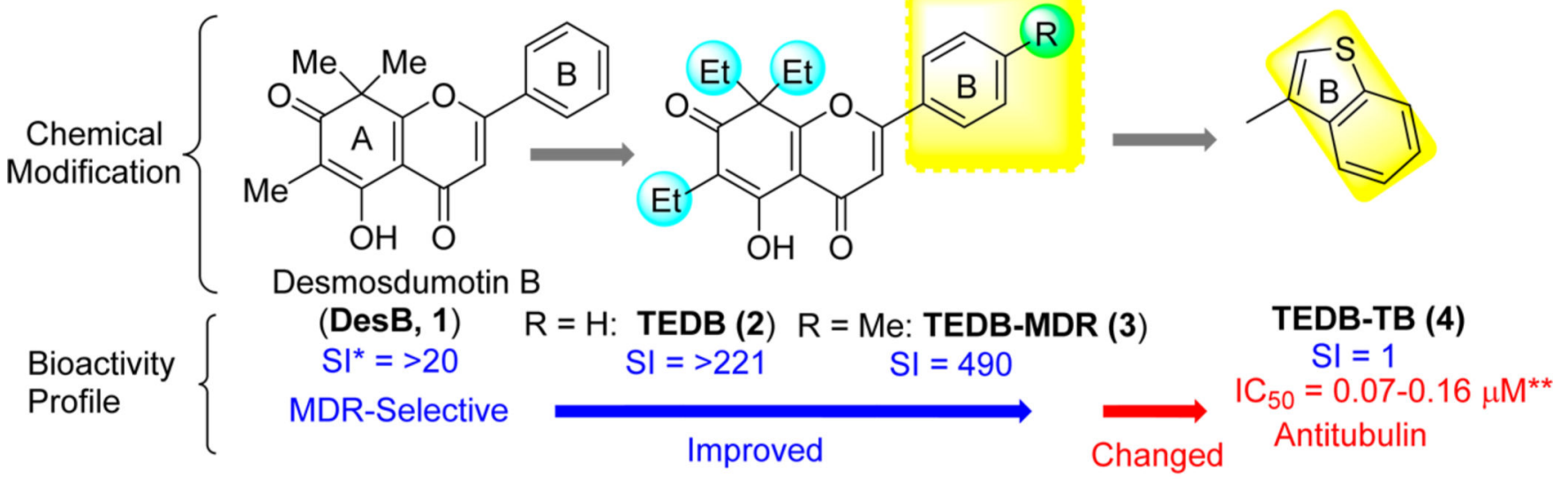

${ }^{*}$ SI:Selective index $=I C_{50}$ non-MDR/IC $C_{50}$ MDR tumor cell ${ }^{* *}$ Cytotoxicity against multiple tumor cell lines

Figure 1.

Structures of desmosdumotin B and related bioactive analogues. 


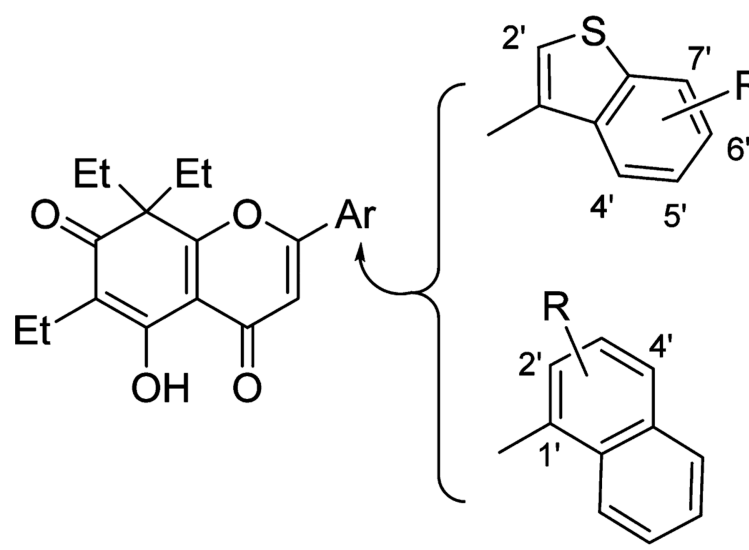

4: $\mathrm{R}=\mathrm{H}$

6: $\mathrm{R}=4^{\prime}-\mathrm{OH}, 10: \mathrm{R}=4^{\prime}-\mathrm{OMe}$

7: $\mathrm{R}=5^{\prime}-\mathrm{OH}, 11: \mathrm{R}=5^{\prime}-\mathrm{OMe}$

8: $\mathrm{R}=6$ '-OH,

9: $\mathrm{R}=7$ '-OH, 12: $\mathrm{R}=$ 7'-OMe

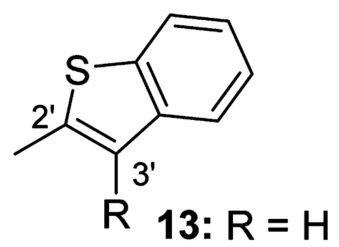

14: $\mathrm{R}=\mathrm{OH}$

5: $\mathrm{R}=\mathrm{H}$

15: $\mathrm{R}=2^{\prime}-\mathrm{OH}$

16: $\mathrm{R}=4^{\prime}-\mathrm{OH}$

17: $\mathrm{R}=4^{\prime}-\mathrm{OMe}$

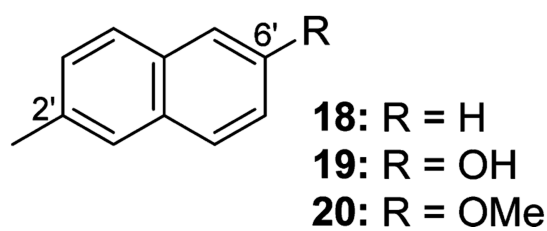

Figure 2.

Structures of TEDB-TB analogues. 
<smiles>CCC1=C(O)c2c(oc(C(C)(C)F)cc2=O)OC1(CC)CC</smiles>

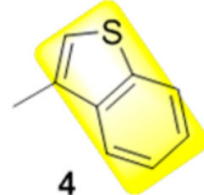

4
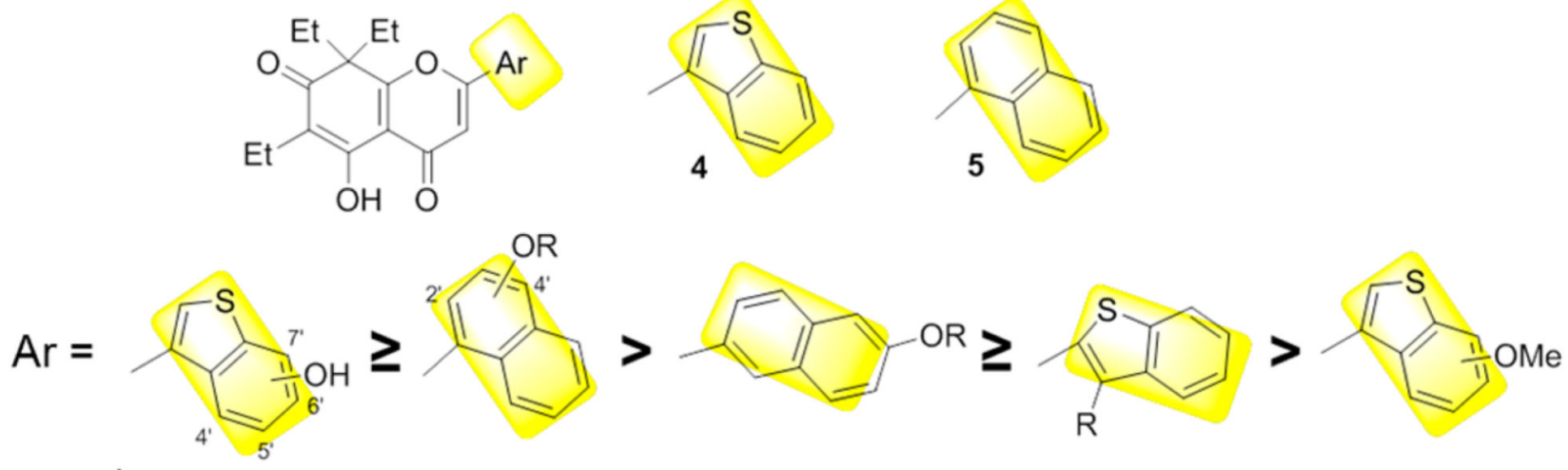

\begin{tabular}{l|l} 
& Position of $\mathrm{OH}$ \\
\hline $\begin{array}{l}\text { Anti- } \\
\text { proliferative } \\
\text { activity }\end{array}$ & $\begin{array}{l}4^{\prime}-, 5^{\prime}-, 6^{\prime}-, 7^{\prime}- \\
\text { almost equal }\end{array}$
\end{tabular}

$\mathrm{R}$

$\mathrm{R}$

Position of OMe

$\mathrm{H} \approx \mathrm{Me}$

$\mathrm{H} \approx \mathrm{Me}$

$\mathrm{H} \approx \mathrm{OH}^{2}$

$4^{\prime}-, 5^{\prime}->7^{\prime}-$

Figure 3.

Structure-activity relationship of hydroxylated TEDB-TB analogues. SAR study shown in Table 1 summarized: (1) 4'-position $\approx 6^{\prime}$-position $>5^{\prime}$-position $\approx 7^{\prime}$-position against HCT-8 and (2) $\mathrm{H}>\mathrm{OH}$ against $\mathrm{PC}-3$. 


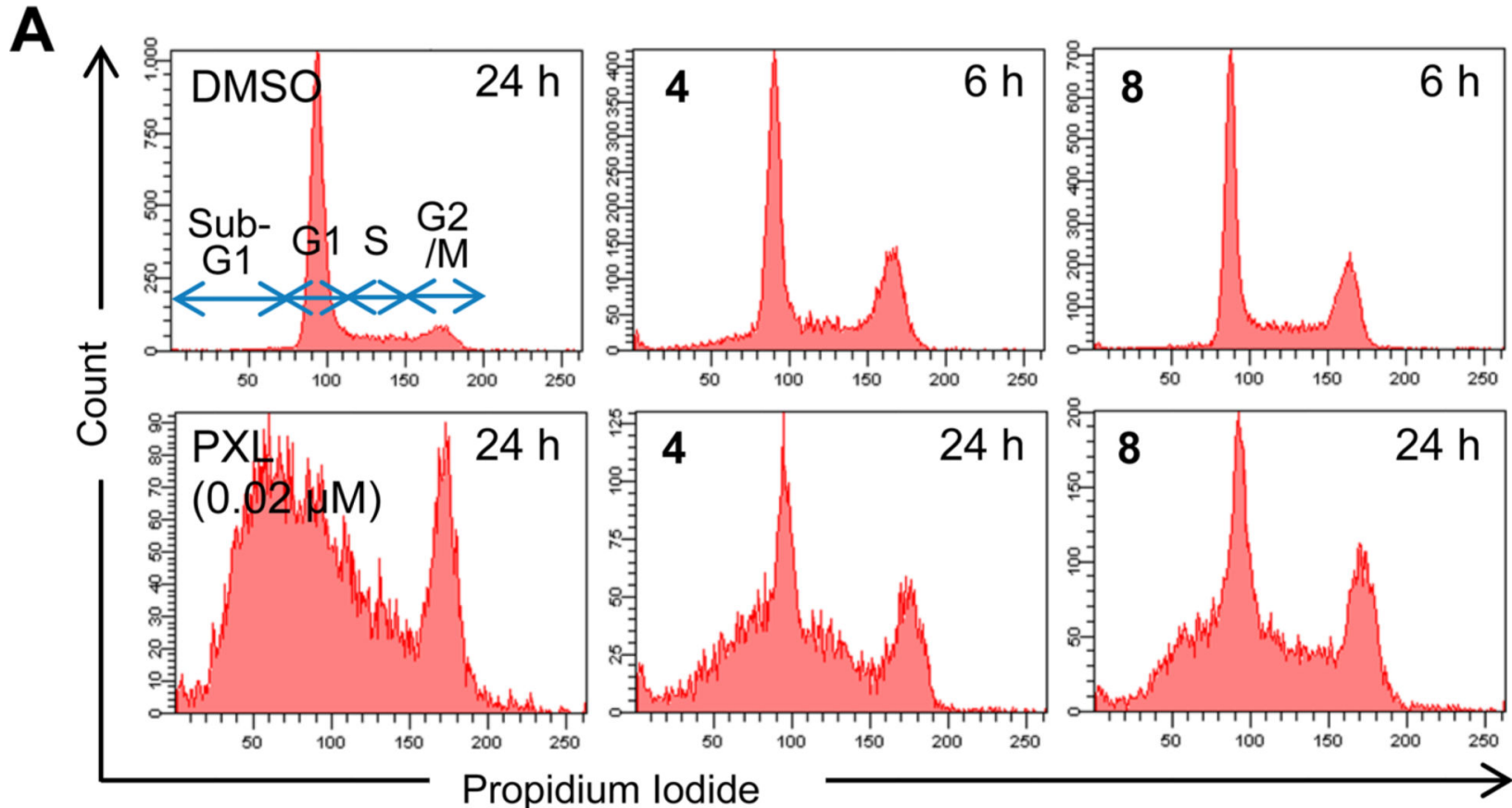

B

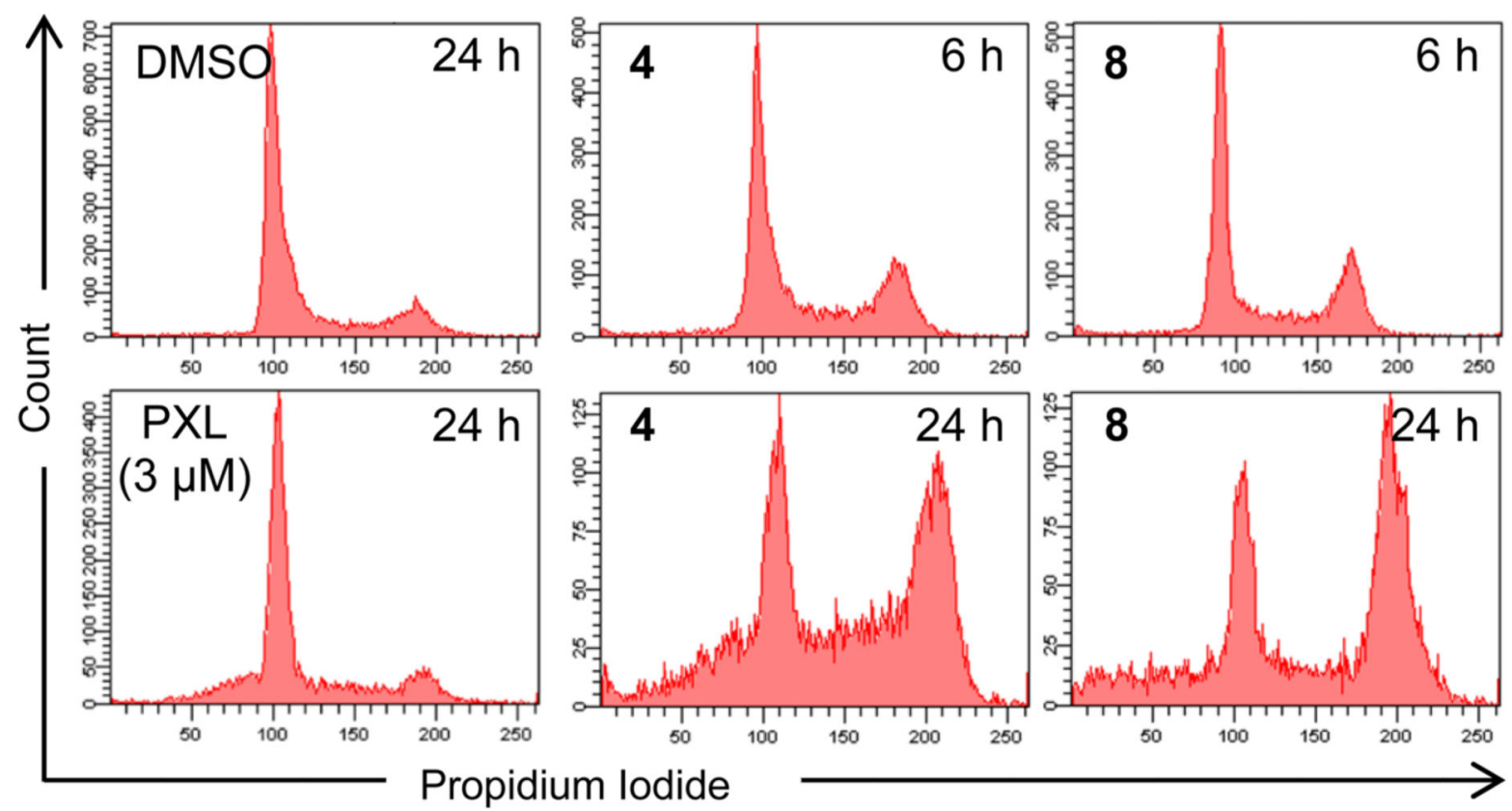

Figure 4.

Effect of compounds on the cell cycle distribution in MDR cells. Chemosensitive KB cell line (A) and its MDR subline (KB-VIN) (B) were treated with vehicle control (DMSO), PXL $(0.02 \mu \mathrm{M}$ for KB and $3 \mu \mathrm{M}$ for KB-VIN), 4, or 8 for 6 or $24 \mathrm{~h}$, as indicated. Cell cycle progression was analyzed by measuring DNA content using a flow cytometer. Cell cycle phases are indicated as G1 $(2 \mathrm{~N}), \mathrm{S}, \mathrm{G} 2 / \mathrm{M}(4 \mathrm{~N})$, and sub-G1. PXL disrupted cell cycle progression in KB cells at $0.02 \mu \mathrm{M}$, while no significant effect was seen in KB-VIN cells, even at $3 \mu \mathrm{M}$. Accumulation of $\mathrm{G} 2 / \mathrm{M}$ phase as well as $\mathrm{S}$ phase cells was observed in both 
chemosensitive and MDR cells treated with $\mathbf{4}$ and $\mathbf{8}$ at the same concentrations in a timedependent manner. 


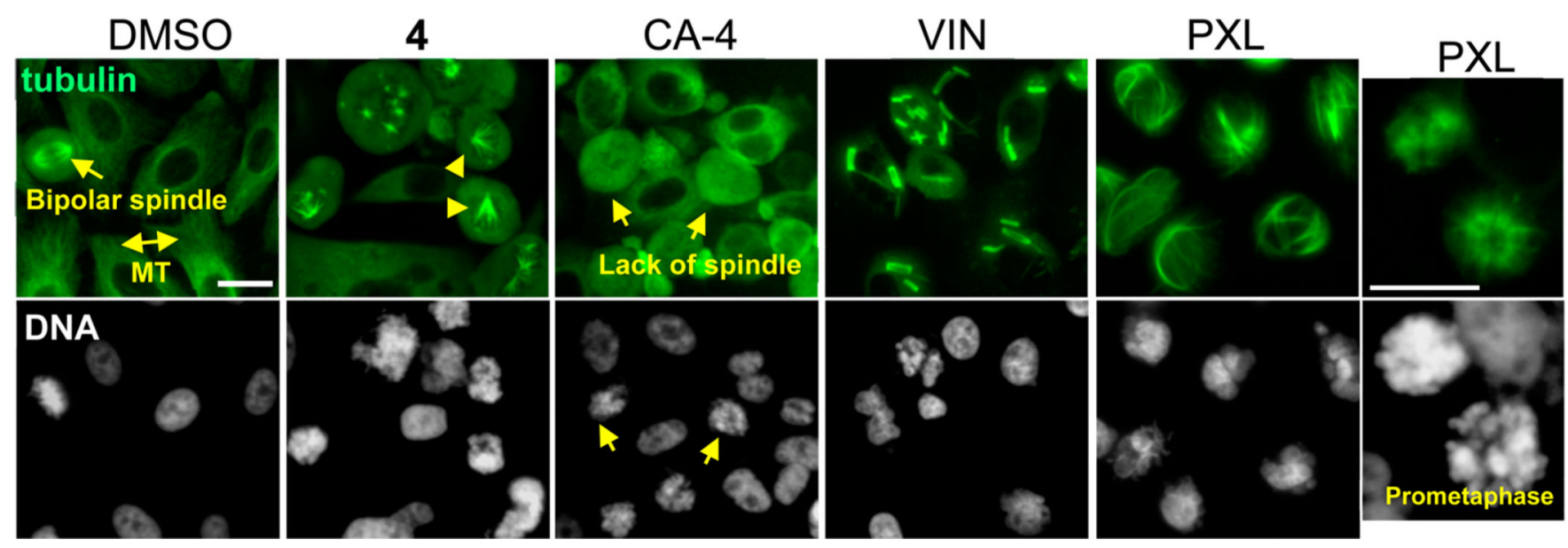

Figure 5.

Disruption of microtubule morphology in PC-3 cells by small molecules. Prostate cancer cells (PC-3) were treated for $24 \mathrm{~h}$ with antimicrotubule agents as indicated (DMSO as vehicle control, $0.2 \mu \mathrm{M}$ compound 4, $0.2 \mu \mathrm{M}$ CA-4, $5 \mu \mathrm{M}$ VIN, $0.2 \mu \mathrm{M}$ PXL). Compounds were used at equitoxic compound concentrations and examined for disruption of microtubule dynamics within $24 \mathrm{~h}$. Microtubules were visualized by immunofluorescence staining using monoclonal antibody to $a$-tubulin (upper panels), and DAPI was used for DNA staining (lower panels). In control cells treated with DMSO, bipolar spindle formation in mitotic cells (arrow) as well as microtubule (MT) networks in interphase cells (double arrow) were observed. Treatment with 4 induced depolymerization of cytosolic microtubules as well monopolar (arrow heads) or multipolar spindle formations in the G2/M-phase. Treatment with CA-4 led to both depolymerization of interphase microtubules and disruption of mitotic spindles (arrows). PXL inhibited the onset of mitosis and arrested cells at prometaphase with condensed chromosomes (right panels). Characteristic bundled microtubules were observed in interphase cells treated with PXL, while tubulin paracrystal formation was observed in cells treated with VIN. Bar, $25 \mu \mathrm{m}$. Additional images including colchicine treatment are shown in the Supporting Information (Figure S1). 
A

Figure 6.
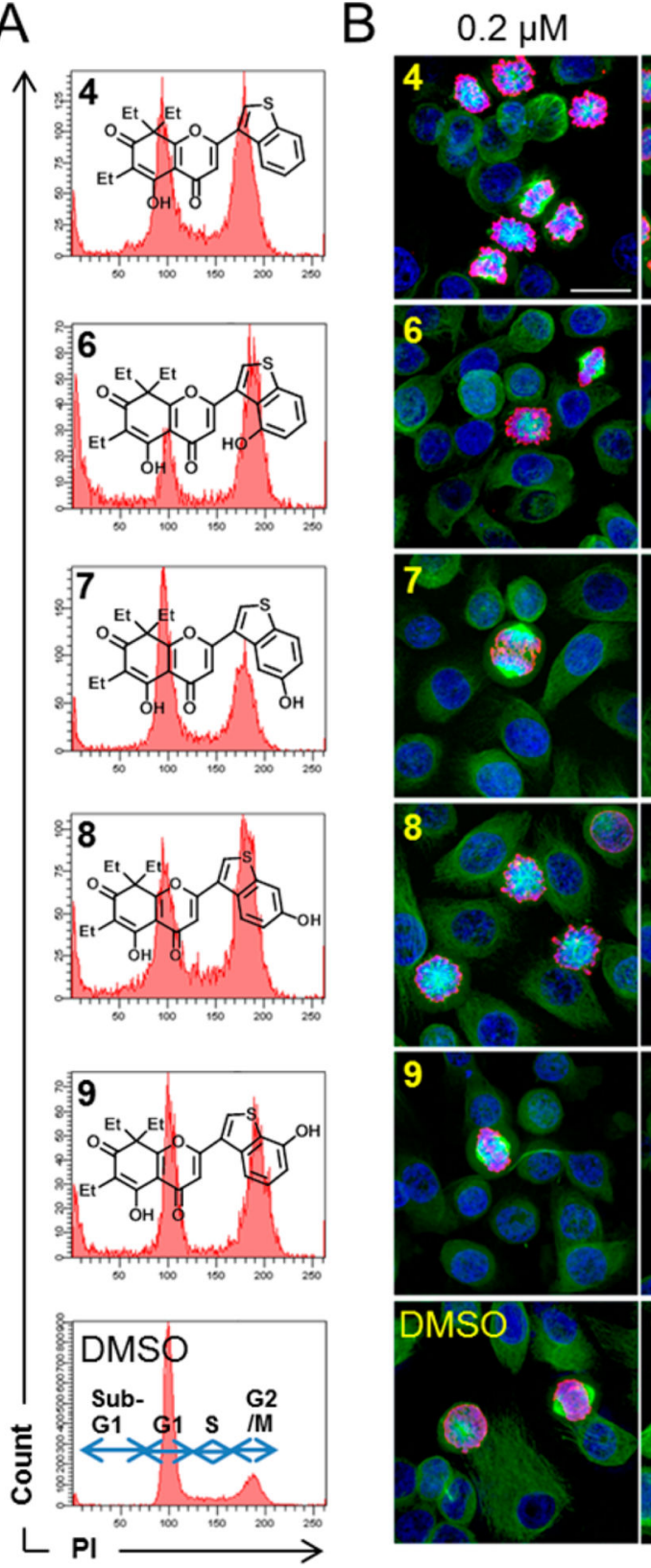

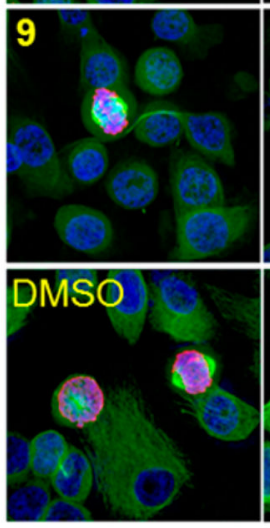

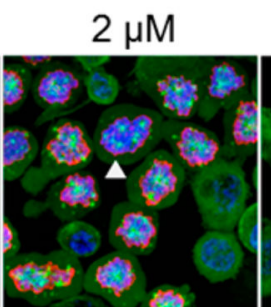

$20 \mu \mathrm{M}$
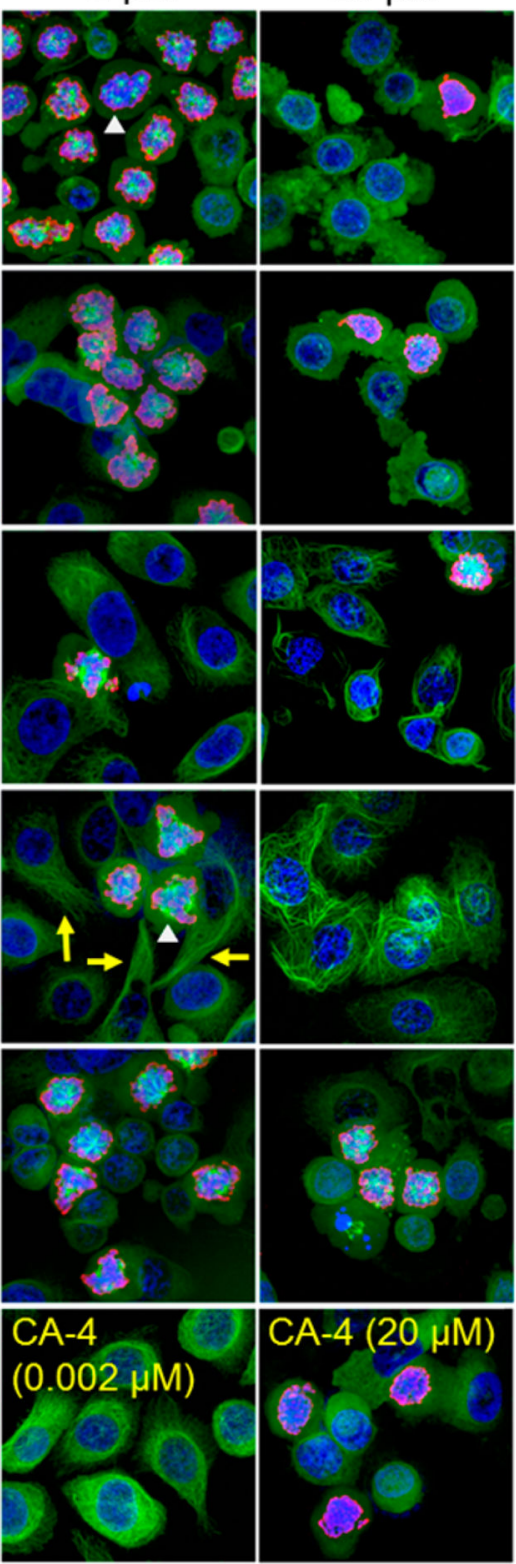

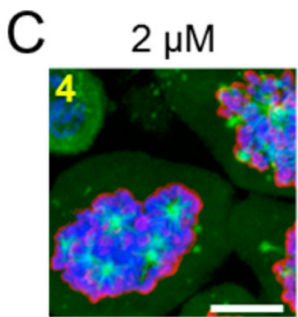

$20 \mu \mathrm{M}$
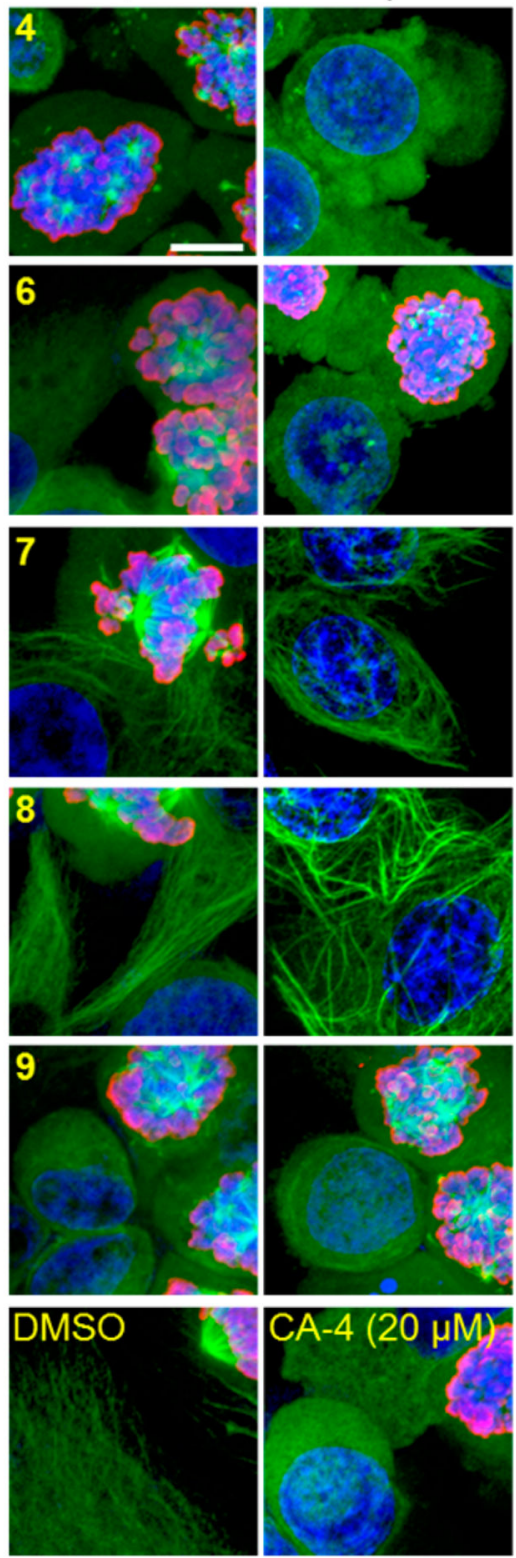

Distinct effects on microtubule morphology by structural modification of compounds. (A) Effect of compounds on cell cycle distribution in PC-3 cells. PC-3 cells were treated for $24 \mathrm{~h}$ with $2 \mu \mathrm{M} \mathrm{4,6,7,8}$, or 9 or vehicle control (DMSO), as indicated. Cell cycle progression was analyzed by flow cytometric analysis. All analogues efficiently induced accumulation of G2/M phase cells. (B) Dose-dependent effects of compounds on microtubule morphology in PC-3 cells. PC-3 cells were treated for $24 \mathrm{~h}$ with $\mathbf{4 , 6 , 7 , 8}$, or 9 at $0.2,2$, or $20 \mu \mathrm{M}$. DMSO was used with the control cells. CA-4 was used at 0.002 or $20 \mu \mathrm{M}$. Cells were stained with antibodies to $a$-tubulin (green) and Ser10-phosphorylated histone H3 (p-H3, red) as a mitotic marker and with DAPI for DNA (blue). Stacked and merged confocal images are presented. TEDB-TB analogues induced cell cycle arrest at prometaphase (p-H3- 
positive) by disrupting bipolar spindle formation. Immature multipolar spindles (white arrow heads) were formed in the cells treated with analogues but were undetectable after CA-4 treatment. Dose-dependent disruption of both interphase microtubules and spindles was observed in cells treated with $\mathbf{4 , 6 , 9}$, or CA-4. In contrast, in cells treated with $\mathbf{7}$ or $\mathbf{8}$, normal interphase microtubules and disrupted spindles were visualized (yellow arrows). Bar, $25 \mu \mathrm{m}$. (C) Higher magnification views. Bar, $10 \mu \mathrm{m}$. Additional images are shown in the Supporting Information (Figure S2). 


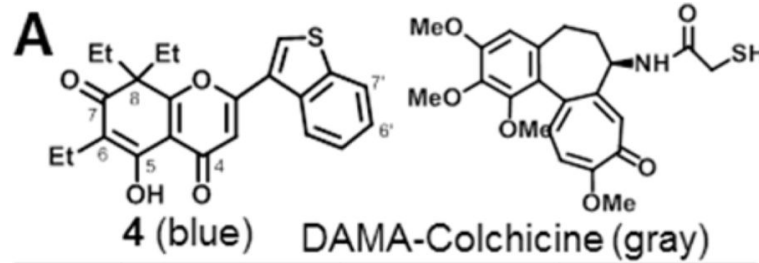

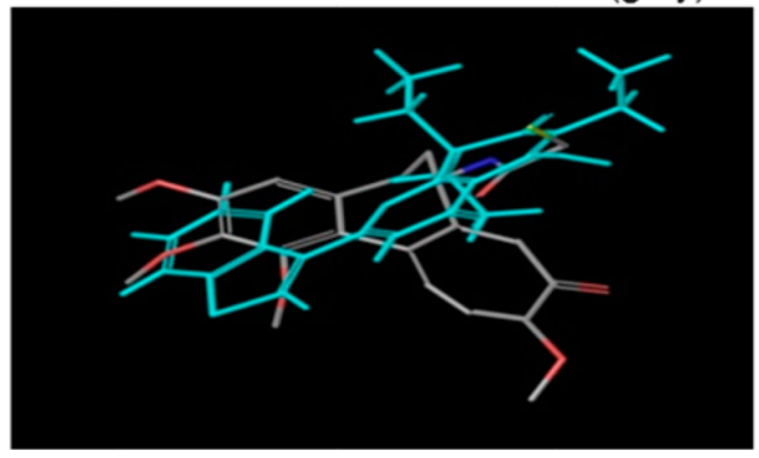

\section{$\mathbf{B}$}

\section{a-tubulin}

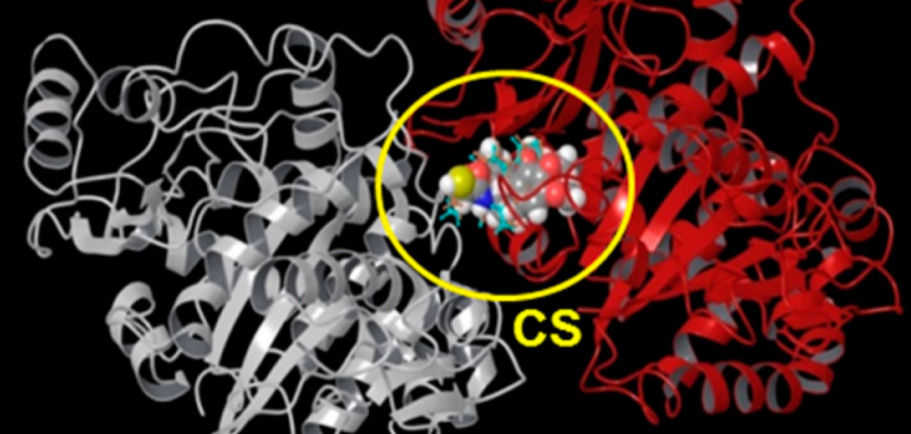

$\boldsymbol{\beta}$-tubulin

Figure 7.

Predicted docking models for $\mathbf{4}$ and $\mathbf{8}$ binding to tubulin. (A) Structures and 3D models of $\mathbf{4}$ (blue skeleton) and DAMA-colchicine (gray skeleton with oxygen in red, nitrogen in blue, and sulfur in yellow). (B) Docking model of $\mathbf{4}$ (blue skeleton), 8 (brown skeleton), and DAMA-colchicine (sphere in 3D with carbon in gray, proton in white, oxygen in red, nitrogen in blue, and sulfur in yellow) in the CS (yellow circle) of the tubulin crystal structure (PDB ID: 1SA0), shown as a ribbon diagram. 

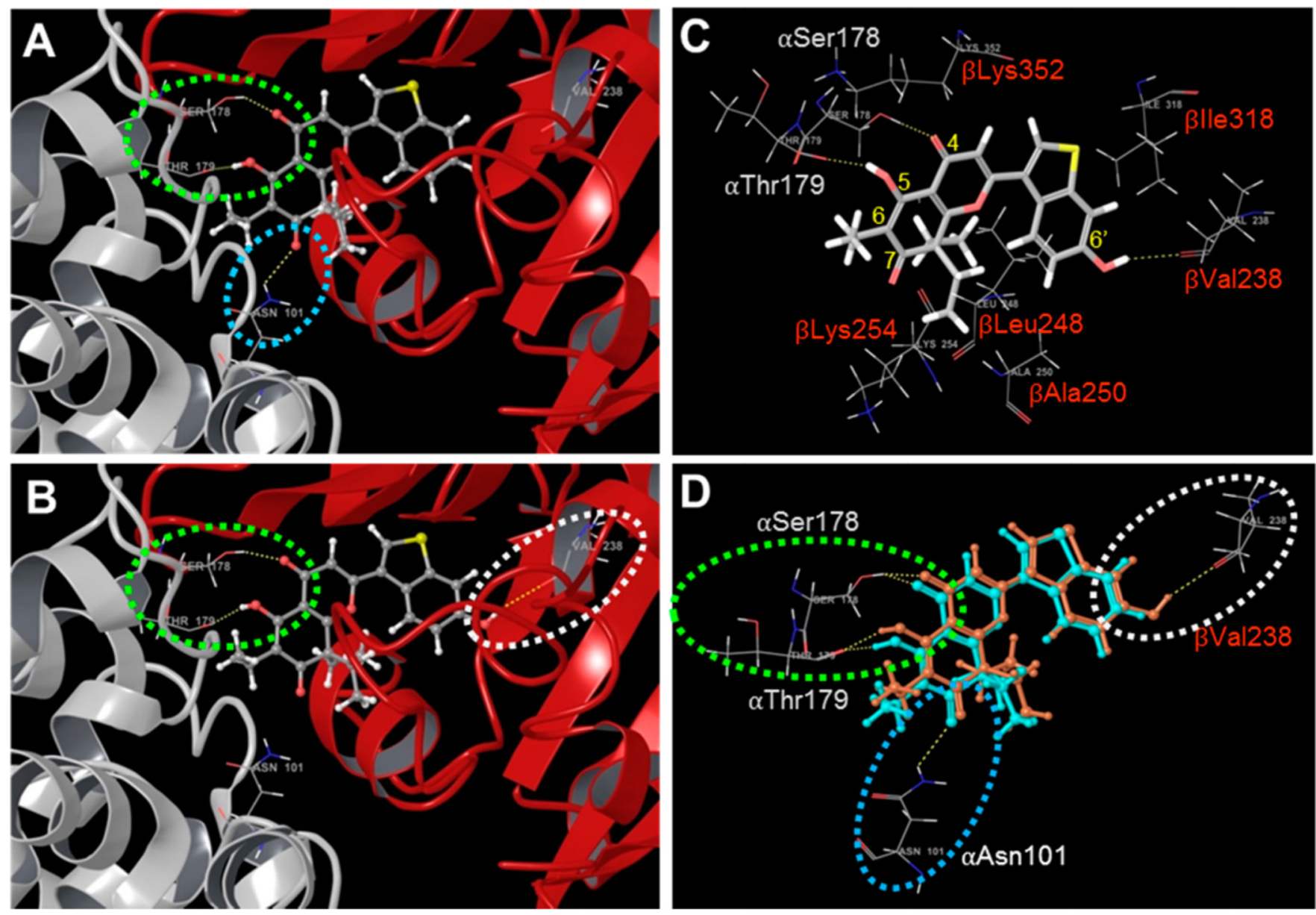

Figure 8.

Predicted docking models for $\mathbf{4}$ and $\mathbf{8}$ binding in the CS. Crystal structures (PDB ID: 1SA0) of $\alpha$ - (white) and $\beta$-tubulin (red) are shown as ribbon diagrams. H-bonds calculated to be less than $3 \AA$ between protein and compounds are represented by dashed lines. Docking models of compounds (gray skeleton with oxygen in red and sulfur in yellow) 4 (A) and 8 (B) in the CS are shown. Superimposition of docked compound 4 shows H-bonds with the side chains of $a$ Asn101 (dashed blue circle) and $a$ Ser178 and $a$ Thr179 (dashed green circle). In contrast, with $\mathbf{8}$, there is a H-bond between $\mathbf{8}$ and the side chain of $\beta \mathrm{Val} 238$ (dashed white circle), and the H-bond between $\mathbf{8}$ and the side chain of $a \mathrm{Asn} 101$ is absent. (C) Docking mode of $\mathbf{8}$ in the CS. Superimposition of docked compound $\mathbf{8}$ shows H-bonds between 8 and $a$ Ser178 and $a$ Thr179 in $a$-tubulin ( $\alpha$ Ser178, $\alpha$ Thr179) and between 8 and $\beta \mathrm{Val238}$. (D) Comparison of the docking mode of $\mathbf{8}$ (brown) with that of $\mathbf{4}$ (blue) in CS. Superimposition of docked compounds $\mathbf{4}$ and $\mathbf{8}$ shows conserved H-bonds with $a$ Ser178 and $a$ Thr179 (dashed green circle). An additional H-bond between the C-7 oxygen of 4 and $a$ Asn 101 (dashed blue circle) was also observed. In contrast, a H-bond between the C-6' hydroxyl group of $\mathbf{8}$ and the side chain of $\beta \mathrm{Val} 238$ (white circle) was unambiguous, while no H-bond occurred with $a$ Asn 101. 
A<smiles>[R]Cc1cccc2c(-c3cc(=O)c4c(o3)C(CC)(CC)C(=O)C(CC)=C4O)csc12</smiles>

4: $\mathrm{R}=\mathrm{H}$ (blue)

6: $\mathrm{R}=4$ '-OH (green)

7: $\mathrm{R}=5^{\prime}-\mathrm{OH}$ (yellow)

8: $\mathrm{R}=6$ '-OH (brown)

9: $\mathrm{R}=7^{\prime}-\mathrm{OH}$ (pink)

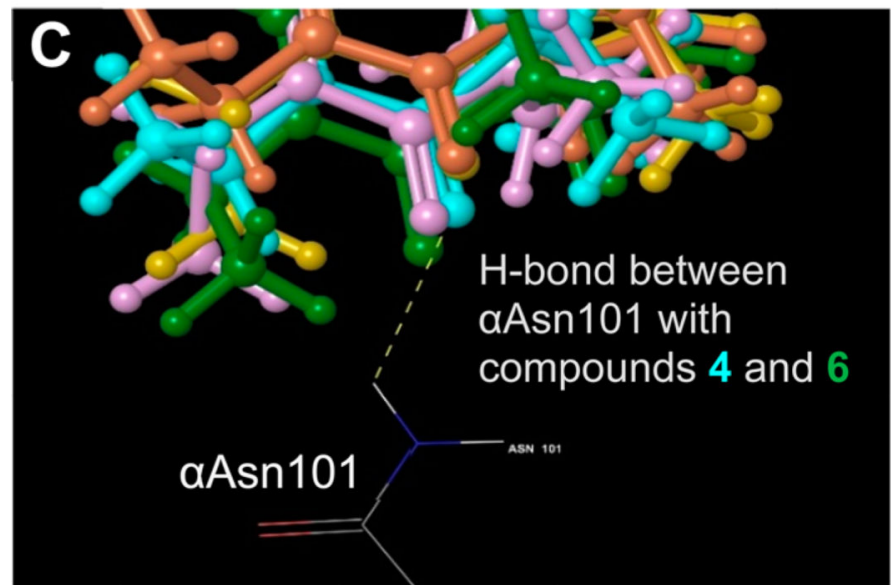

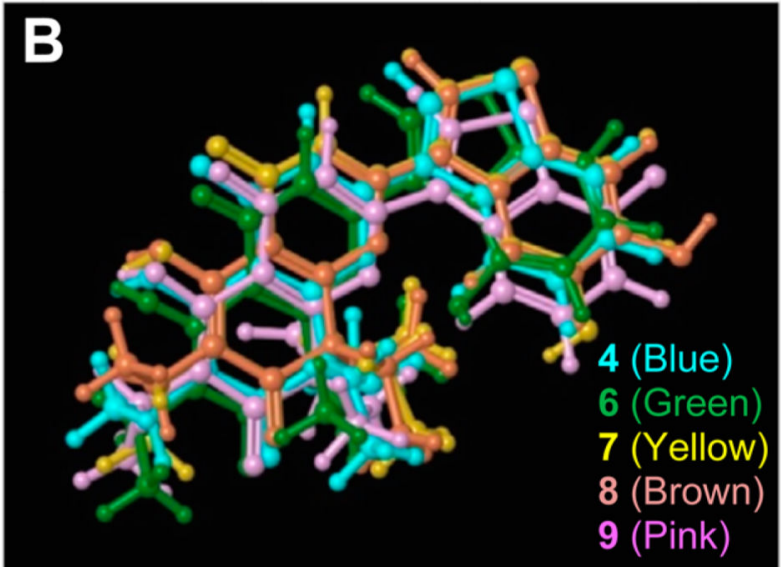

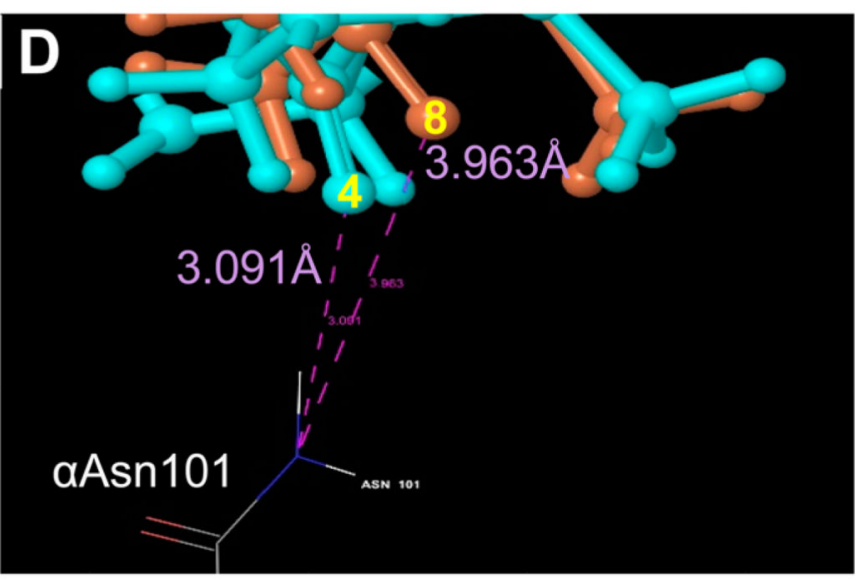

Figure 9.

Hydrogen bonds between $\mathbf{4}$ analogues and tubulin in the CS. Structures (A) and conformations (B) of $\mathbf{4}$ and analogues are presented. The same docking pattern is shown among all compounds, except 9. (C) H-bond between C-7 oxygen of compounds and $a$ Asn101. A H-bond calculated as less than $3 \AA$ occurred in 4 and 6. (D) Comparison of distance between oxygen on compound and nitrogen on $a \mathrm{Asn} 101$. The N-O distances for 4 $(3.091 \AA)$ and 8 (3.963 $\mathrm{A})$ differed by over $0.8 \AA$. 
<smiles>CCCC1(CC)C(=O)C(C(C)C)=C(O)c2c1oc(Br)cc2=O</smiles><smiles>COc1cccc2c(C=O)csc12</smiles>

24: $\mathrm{R}=5-\mathrm{OMe}$

25: $\mathrm{R}=4-\mathrm{OMe}$

26: $\mathrm{R}=6-\mathrm{OMe}$

27: $\mathrm{R}=7-\mathrm{OMe}$

Scheme 1.

Syntheses of New Analogues of 4 and 5a

aReagents and conditions: (a) $\mathrm{ArCHO}, 50 \% \mathrm{KOH}, \mathrm{EtOH}, \mathrm{rt}$; (b) $\mathrm{I}_{2}$ (cat.), DMSO, $\mathrm{H}_{2} \mathrm{SO}_{4}$ (cat.), $90-95^{\circ} \mathrm{C}, 1 \mathrm{~h}$; (c) $\mathrm{BBr}_{3}, 0{ }^{\circ} \mathrm{C}$ to rt.<smiles>COc1ccc2cc(C=O)ccc2c1</smiles>

29: 2-OMe

30: 4-OMe 


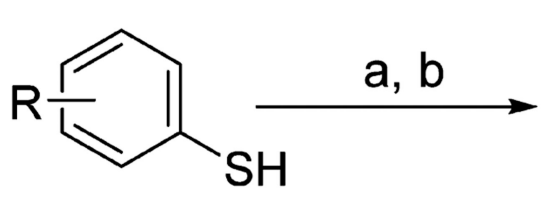

32: $\mathrm{R}=p-\mathrm{OMe}$

33: $\mathrm{R}=m-\mathrm{OMe}$

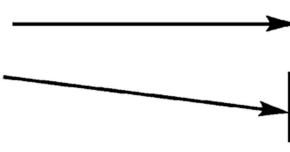

34: $\mathrm{R}=\mathrm{o}-\mathrm{OMe}$<smiles>Cc1csc2ccccc12</smiles>

43<smiles></smiles>

35: $\mathrm{R}=5-\mathrm{OMe}$ 36: $\mathrm{R}=4-\mathrm{OMe}$

$37: \mathrm{R}=6-\mathrm{OMe}$

38: $R=7-O M e$ $\stackrel{\mathrm{c}, \mathrm{d}}{\longrightarrow}$<smiles></smiles>

24: $\mathrm{R}=5-\mathrm{OMe}$

25: $\mathrm{R}=4-\mathrm{OMe}$ 26: $\mathrm{R}=6-\mathrm{OMe}$

27: $\mathrm{R}=7-\mathrm{OMe}$<smiles>COc1csc2ccccc12</smiles>

44<smiles>COc1c(C=O)sc2ccccc12</smiles>

28

Scheme 2.

Preparation of Methoxybenzothiophenecarboxaldehydesa

aReagents and conditions: (a) $\mathrm{CH}_{3} \mathrm{COCH}_{2} \mathrm{Cl}, \mathrm{K}_{2} \mathrm{CO}_{3}, \mathrm{DMF}$, rt; (b) PPA, $100{ }^{\circ} \mathrm{C}$; (c) $\mathrm{NBS}$, $(\mathrm{PhCOO})_{2}, \mathrm{CCl}_{4}$, reflux; (d) $\mathrm{HMTA}, \mathrm{CHCl}_{3}$, reflux, then 50\% $\mathrm{HOAc}$, reflux; (e) $\mathrm{NaOMe}$, $\mathrm{CuO}, \mathrm{CuI}, \mathrm{KI}, \mathrm{DMF}$, reflux; (f) $n$-BuLi, THF, $-78^{\circ} \mathrm{C}$, then DMF. 


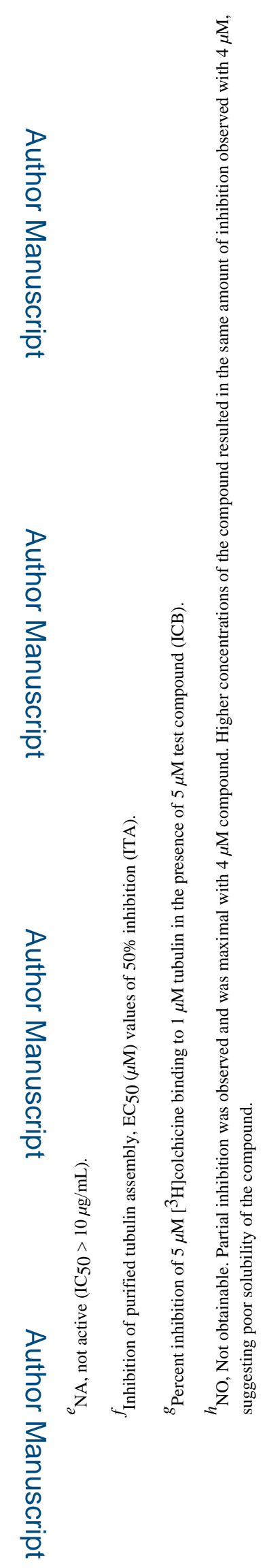

